\title{
Interactions between climate and vegetation during the Lateglacial period as recorded by lake and mire sediment archives in Northern Italy and Southern Switzerland
}

\author{
Elisa Vescovi ${ }^{\mathrm{a}, \mathrm{b}, *}$, Cesare Ravazzi ${ }^{\mathrm{b}}$, Enrico Arpenti ${ }^{\mathrm{b}}$, Walter Finsinger ${ }^{\mathrm{a}, \mathrm{c}}$, Roberta Pini $^{\mathrm{b}}$, \\ Verushka Valsecchi $^{\mathrm{a}, \mathrm{d}}$, Lucia Wick ${ }^{\mathrm{e}}$, Brigitta Ammann ${ }^{\mathrm{a}}$, Willy Tinner ${ }^{\mathrm{a}, \mathrm{f}}$ \\ ${ }^{a}$ Institute of Plant Sciences, University of Bern, Altenbergrain 21, CH-3013 Bern, Switzerland \\ ${ }^{\mathrm{b}}$ C.N.R. - Institute for the Environmental Dynamics, via Pasubio 5, 24044 Dalmine, Italy \\ ${ }^{\mathrm{c}}$ Institute of Environmental Biology, Section Palaeoecology, Utrecht University, Laboratory of Palaeobotany and Palynology, \\ Budapestlaan 4, NL 3584 CD Utrecht, The Netherlands \\ dDepartment of Earth Science "Ardito Desio", University of Milan, via Mangiagalli 34, 20133 Milano, Italy \\ ${ }^{\mathrm{e}}$ Institute of Prehistory and Archaeological Science, University of Basel, Spalenring 145, 4055 Basel, Switzerland \\ ${ }_{\mathrm{f}}^{\mathrm{f}}$ Institute of Terrestrial Ecology, ETH Zürich, Universitätstrasse 16, CH-8092 Zürich, Switzerland
}

Received 27 July 2006; received in revised form 14 March 2007; accepted 15 March 2007

\begin{abstract}
We reconstruct the vegetational history of the southern side of the Alps at 18,000-10,000 cal yr BP using previous and new AMS-dated stratigraphic records of pollen, stomata, and macrofossils. To address potential effects of climatic change on vegetation, we compare our results with independent paleoclimatic series (e.g. isotope and chironomid records from the Alps and the Alpine forelands). The period before 16,000 cal yr BP is documented only at the lowland sites. The previous studies used for comparison with our new Palughetto record, however, shows that Alpine deglaciation must have started before 18,000-17,500 cal yr BP south of the Alps and that deglaciated sites were colonized by open woods and shrublands (Juniperus, tree Betula, Larix, Pinus cembra) at ca 17,500 cal yr BP. The vegetational history of a new site (Palughetto, $1040 \mathrm{~m}$ a.s.l.) is consistent with that of previous investigations in the study region. Our results show three conspicuous vegetational shifts delimited by statistically significant pollen zones, at ca 14,800-14,400, 13,300-12,800 and 11,600-11,200 cal yr BP. At sites situated above $1000 \mathrm{~m}$ a.s.l. (e.g. Palughetto, Pian di Gembro) forests expanded in alpine environments at ca 14,500 cal yr BP (onset of Bølling period, GI-1 in the Greenland ice record). At the same time, rather closed treeline communities of the lowlands were replaced by dense stands of Pinus sylvestris and Betula. These early forests and shrublands consisted of Larix, P. cembra, Juniperus, P. sylvestris, Pinus mugo, and Betula, and had become established at ca 16,000 cal yr BP, probably in response to a temperature increase. If combined with other records from the Southern Alps, our data suggest that treeline ascended by ca $800-1000 \mathrm{~m}$ in a few centuries at most, probably as a consequence of climatic warming at the beginning of the Bølling period. At 13,100-12,800 cal yr BP the onset of a long-lasting decline of $P$. sylvestris was accompanied by the expansion of Quercus and other thermophilous tree taxa below ca $600 \mathrm{~m}$ a.s.l. This vegetational change was probably induced by a shift to warmer climatic conditions before the onset of the Younger Dryas, as indicated by independent paleoclimatic records. Only a few centuries later, at ca 12,700-12,500 cal yr BP, an expansion of herbaceous taxa occurred in the lowlands as well as at higher altitudes, documenting an opening of forested habitats. This change coincided with the beginning of the Younger Dryas cooling (GS-1), which according to the paleoclimatic series (e.g. oxygen isotope series), started at 12,700-12,600 cal yr BP and lasted for about 1000 years. Environments south of the Alps responded markedly to climatic warming at the onset of the Holocene (11,600-11,500 cal yr BP). Thermophilous trees that had declined during the Younger Dryas re-expanded very rapidly in the lowlands and reached the high altitude sites below ca $1500 \mathrm{~m}$ a.s.l. within a few centuries at most. Our study implies that the synchronous vegetational changes observed over wide areas were probably a consequence of abrupt climatic
\end{abstract}

\footnotetext{
${ }^{*}$ Corresponding author. Institute of Plant Sciences, University of Bern, Altenbergrain 21, CH-3013 Bern, Switzerland. Tel.: + 41316314922 ; fax: +416314942 .

E-mail address: elisa.vescovi@ips.unibe.ch (E. Vescovi).
} 
shifts at the end of the Last Glacial Maximum (LGM) and during the Lateglacial. We emphasize that important vegetational changes such as the expansion of forests occurred millennia before the onset of similar processes in northwestern and central Europe.

(C) 2007 Elsevier Ltd. All rights reserved.

\section{Introduction}

Recent paleovegetational records with improved chronology and resolution have provided new insights regarding the vegetational history of the southern side of the Alps (e.g. Wick, 1996; Tinner et al., 1999; Pini, 2002; Finsinger et al., 2006). If compared with independent paleoenvironmental records, these new records give the opportunity to explore whether vegetational changes were related to climatic variations. This question has not been addressed in detail so far for northern Italy and adjacent areas with regard to the Lateglacial period, i.e. the interval between the end of the Last Glacial Maximum (LGM) at 18,000 cal yr BP (Lambeck et al., 2002; Sarnthein et al., 2003; Kucera et al., 2005) and the beginning of the Holocene (i.e. 11,550 cal yr BP, Schwander et al., 2000). Although the southern slope of the Alps was extensively glaciated during the LGM (Ehlers and Gibbard, 2004), conifer and several broad-leaved tree species survived in the Po Plain and along the southeastern Alpine border (Ravazzi et al., 2004). Therefore, this area may be particularly interesting for understanding the European postglacial re-afforestation dynamics.

In this study, we present a new high-resolution pollen record from the Palughetto mire (Cansiglio Plateau, northeastern Italy) (Fig. 1). These results are then compared with other well-dated high-resolution data from the southern side of the Alps (Fig. 1) to assess the spatial extent and consistency of the palaeovegetational patterns observed. Using quantitative techniques we address whether similar biostratigraphical changes (pollen zone boundaries) during the Lateglacial were synchronous in our area and coeval with vegetational changes in neighbouring regions (e.g. Central Europe). In a further step we compare the pollen-inferred palaeovegetational reconstructions with independent proxies of climatic change, such as continental records from north of the Alps (von Grafenstein et al., 1999; Heiri and Millet, 2005) and the

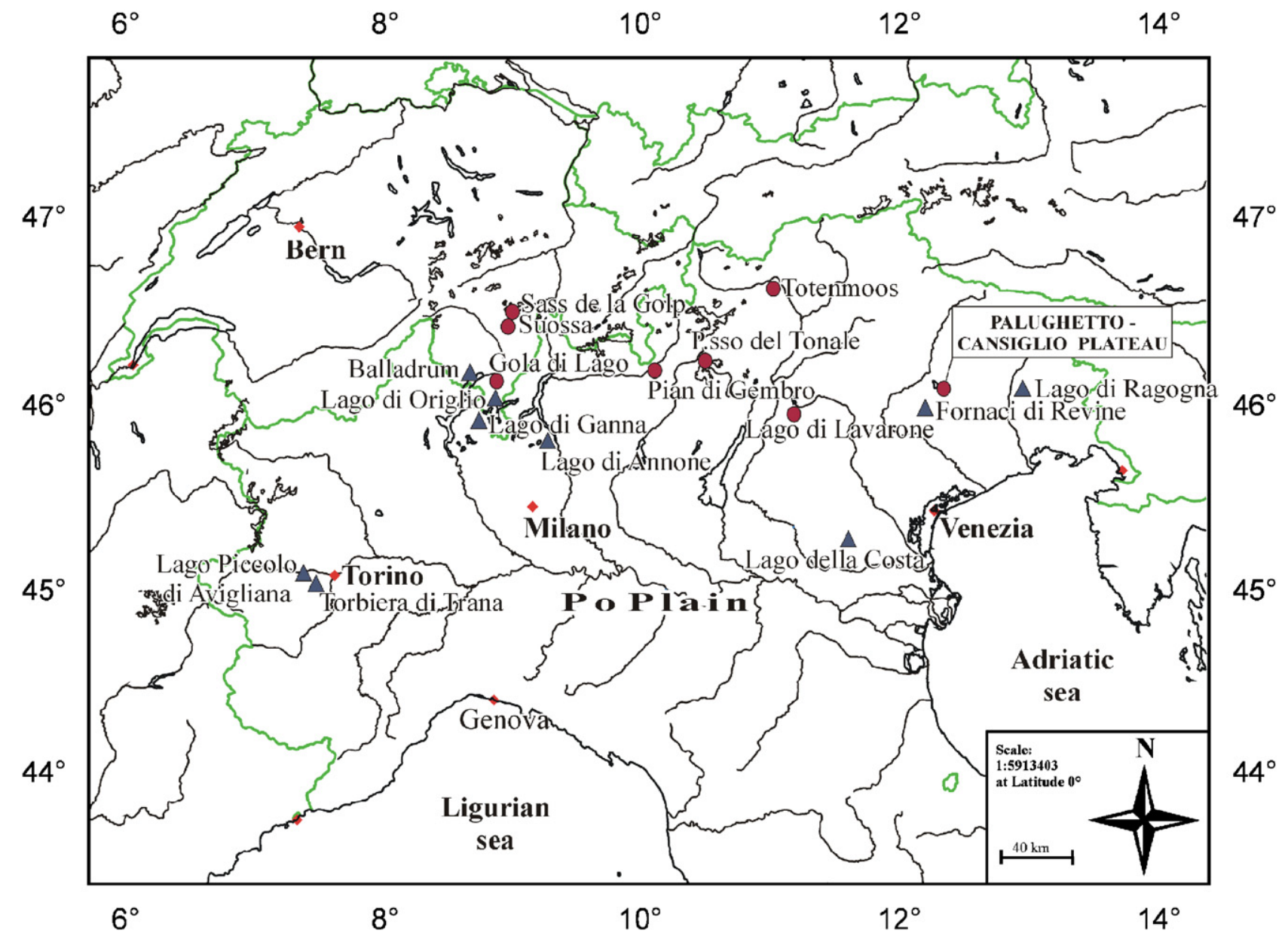

Fig. 1. Location of important sites mentioned in the present paper. Symbols: $\boldsymbol{\Lambda}=$ lowland sites, $\boldsymbol{\bullet}=$ high altitude sites. 

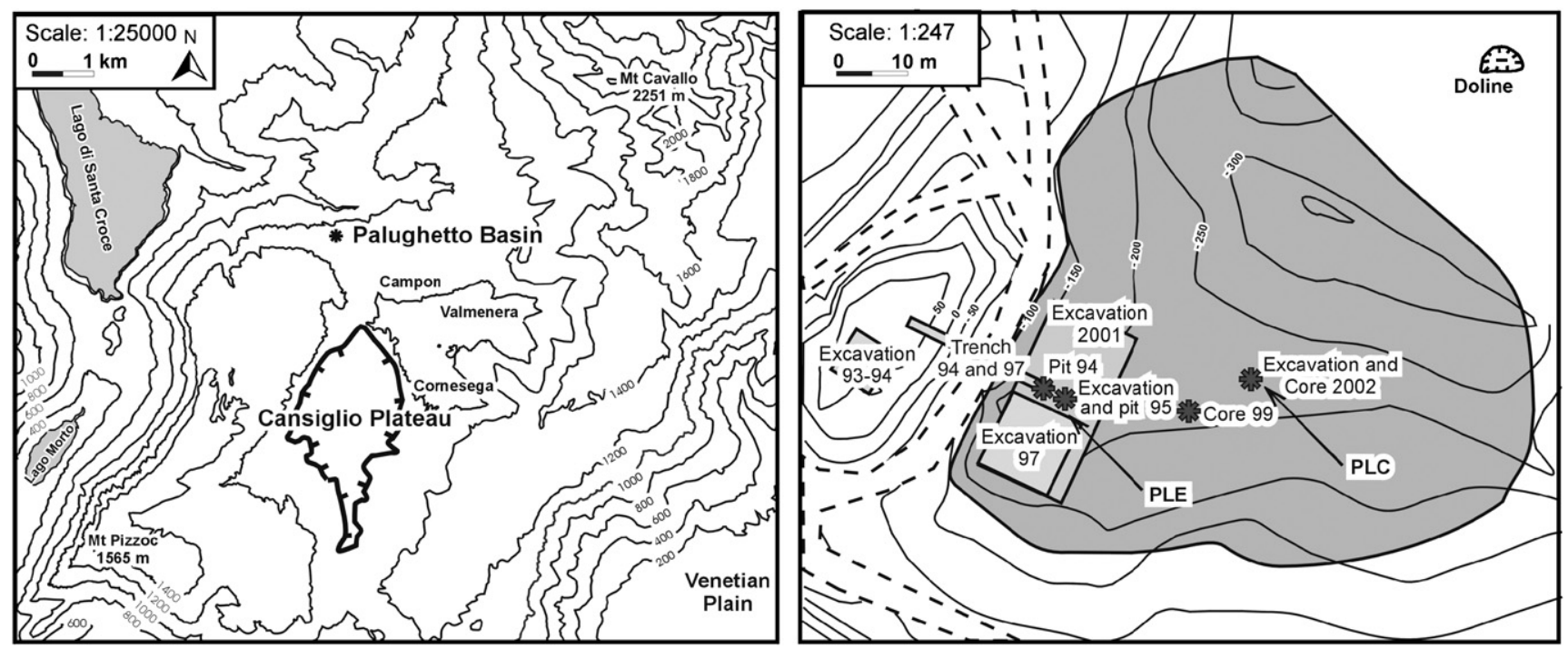

Fig. 2. Simplified maps of (a) the Cansiglio plateau with the border of the polje and (b) the Palughetto basin with the position of the trench, pits, excavations, and cores.

Greenland oxygen-isotope records (Johnsen et al., 1992; Dansgaard et al., 1993) to discuss possible linkages between vegetational and climatic changes.

\section{Material}

\subsection{Site description of the Palughetto mire}

The Palughetto mire (1040 $\mathrm{m}$ a.s.1.) is located in the eastern Venetian Pre-Alps (Province of Belluno, Italy) (Fig. 1) on the Northern edge of the Cansiglio karstic Plateau (Jurassic-Cretaceous limestone platform) (Sartorio, 1987; Antonelli et al., 1990). The Plateau is a polije with one main central depression at $900-1000 \mathrm{~m}$ a.s.1. (Lehmann, 1959), which is bordered by smooth ridges that commonly rise to about $1300-1400 \mathrm{~m}$ except in the east, where higher elevations occur (Mt. Cavallo, $2251 \mathrm{~m}$ a.s.l.; Fig. 2a).

The last advance of the Piave glacier during the LGM covered the plateau on its northern and western sides, but it did not reach elevations below $1040 \mathrm{~m}$ a.s.l. At the northern edge of the plateau glacier deposits obstructed the path of surface waters to the deep karstic system and dammed a small intra-morainic lake, the Palughetto basin. The basin has an irregular off-circular form and is ca $90 \mathrm{~m}$ long and $70 \mathrm{~m}$ broad (Fig. 2b). The site was settled by Late Palaeolithic (Epigravettian) hunters at the Lateglacial/ Holocene transition (Avigliano et al., 2000).

At present the climate is cool-temperate without summer drought. Mean annual air temperature is $11-12^{\circ} \mathrm{C}$, the January mean is $-3^{\circ} \mathrm{C}$, and the July mean is $15^{\circ} \mathrm{C}$. Mean annual precipitation is $1700-1900 \mathrm{~mm}$ (Di Anastasio, 1995). The Cansiglio-Cavallo ridge represents an important barrier for the warm and humid southern air masses originating from the Mediterranean Sea basin. In contrast to nearby Mediterranean climates, precipitation here is concentrated during autumn and spring. During the winter period the climate is harsh due to cold winds from the northeast.

The forest vegetation of the area is dominated by Fagus sylvatica and Abies alba at altitudes between 800 and $1600 \mathrm{~m}$ a.s.1., followed at higher elevations by a narrow subalpine Picea abies-belt, which forms the timberline at $1700-1800 \mathrm{~m}$ a.s.l. P. abies is also abundant on the plateau because of historical plantations. Pinus mugo-shrubs extend in the subalpine belt and along avalanche tracks. The alpine vegetation is mainly formed by calciphilous Sesleria varia-Carex sempervirens grasslands, including plants of cold steppe (e.g. Linum alpinum), screes (e.g. Dryas octopetala), and snow beds (dwarf Salix species).

\subsection{Records used for the Southern Alpine comparison of pollen biostratigraphies}

For comparison with the Palughetto record we selected four sites (Lago di Origlio, Lago di Annone, Pian di Gembro, and Lago Piccolo di Avigliana; Wick, 1996; Tinner et al., 1999; Pini, 2002; Finsinger et al., 2006; Fig. 1, Table 1) that have high temporal resolution and precision. In addition, other important sites with lower temporal precision and/or resolution (e.g. Lago di Ganna, Gola di Lago) or that have not been published yet (e.g. Lago della Costa, Lago di Lavarone) are considered in the discussion. Among the sites used for the comparison Lago della Costa (Euganei hills, northeastern Italy) is the only one not affected by Quaternary glaciations (Vai and Cantelli, 2004; Fig. 1).

The records discussed in this study include mountain sites (Gola di Lago, Lago di Lavarone, Pian di Gembro) climatically similar to Palughetto, although the rainfall amount varies considerably in the region (e.g. $1700-1900 \mathrm{~mm}$ of annual precipitation at Palughetto vs. 
Table 1

Key information of the sites considered in the present paper

\begin{tabular}{|c|c|c|c|c|}
\hline Site used for comparison & Region & $\begin{array}{l}\text { Altitude } \\
\text { (m a.s.l.) }\end{array}$ & Age range (cal yr BP) & Authors \\
\hline Lago Piccolo di Avigliana & Piedmont, Italy & 353 & ca. $6000->17,400$ & Finsinger et al. (2006) \\
\hline Lago di Annone & Lombardy, Italy & 374 & $7800->16,500$ & Wick (1996) \\
\hline Lago di Origlio & Ticino, Switzerland & 416 & $0->18,000$ & Tinner et al. (1999) \\
\hline Palughetto - Cansiglio Plateau & Veneto, Italy & 1040 & $0->15,500$ & Avigliano et al. (2000); Vescovi, Unpubl. Data \\
\hline Pian di Gembro & Lombardy, Italy & 1350 & $0->15,500$ & Pini (2002) \\
\hline \multicolumn{5}{|l|}{ Other sites considered } \\
\hline Lago della Costa & Veneto, Italy & 0 & $>23,000$ & Kaltenrieder et al. (2004) \\
\hline Lago di Ragogna & Friuli-Venezia-Giulia, Italy & 188 & $?->17,370$ & Wick (2004), Monegato et al., submitted \\
\hline Fornaci di Revine & Veneto, Italy & 224 & $13,630->23,000$ & Wick (2004), Monegato et al. submitted \\
\hline Torbiera di Trana & Piedmont, Italy & 360 & ca. $11,500->17,400 ?$ & Eicher (1987), Schneider (1977) \\
\hline Balladrum & Ticino, Switzerland & 390 & $0->15,450$ & Hofstetter et al. (2005) \\
\hline Lago di Ganna & Lombardy, Italy & 452 & $300->16,000$ & Schneider and Tobolski (1985) \\
\hline Gola di Lago & Ticino, Switzerland & 970 & $0->14,741$ & Zoller and Kleiber (1971) \\
\hline Lago di Lavarone & Trentino Alto Adige, Italy & 1100 & $0->13,040$ & Arpenti et al., unpubl. \\
\hline Totenmoos & Trentino Alto Adige, Italy & 1718 & $0->13,715$ & Heiss et al. (2005) \\
\hline Suossa & Ticino, Switzerland & 1700 & $0->15,760$ & Zoller and Kleiber (1971) \\
\hline P.sso del Tonale & Lombardy, Italy & 1883 & 0 -ca. 15,000 & Gehrig (1997) \\
\hline Sass de la Golp & Ticino, Switzerland & 1953 & $0->14,300$ & Burga (1980) \\
\hline
\end{tabular}

900-1000 $\mathrm{mm}$ at Pian di Gembro). The other sites are located in the South-Alpine foothills (Lago Piccolo di Avigliana, Lago di Origlio, Lago di Annone, Fornaci di Revine, Lago di Ragogna, ca 200-400 m a.s.1.) and display a much milder climate compared to the mountain sites. There the mean annual temperature is $11-14{ }^{\circ} \mathrm{C}$, the January mean $2-5^{\circ} \mathrm{C}$, and the July mean $21-24^{\circ} \mathrm{C}$. Precipitation varies significantly and ranges between 800 and $2000 \mathrm{~mm}$.

South of the Alps residual thermophilous forests and planted groves are dominated by Quercus petraea and Castanea sativa on acidic soils and by Quercus pubescens and Ostrya carpinifolia on calcareous soils. The mountain belt above is commonly dominated by $F$. sylvatica, except for inner-alpine, continental sites (e.g. Pian di Gembro), where the thermophilous forests are in direct contact with the Picea-belt. P. mugo today forms extensive shrubs only in the eastern Pre-Alps.

\section{Methods}

Geo-archaeological investigations at the Cansiglio Plateau started in 1993-94 and were soon followed by palaeobotanical analyses (1995 and 1997; Fig. 2b). A short report on the radiocarbon-dated macrofossil record has been already published, together with a pollen diagram (Avigliano et al., 2000). The investigations were conducted at the edge of the Palughetto basin, close to the Late Paleolithic settlement. The pollen record covered the time between $12,700{ }^{14} \mathrm{C}$ yr BP and the early Holocene (Pini, Ravazzi and Valsecchi, unpubl.). This record raised some important questions, notably the vegetation dynamics of the Lateglacial afforestation and the effects of the Younger
Dryas (YD) event on the montane environments of intermediate elevations (1000-1400 $\mathrm{m}$ a.s.1.).

To improve the reconstruction of vegetational history, a new succession from the central part of the basin (PLCstratigraphy), about $20 \mathrm{~m}$ distant from the PLE-site (Avigliano et al., 2000), was sampled in November 2002 by metal boxes and parallel cores (Russian corer) in the lower part. After fieldwork, sediments were accurately described and stored in a dark cold room before subsampling.

Sediment subsamples $\left(1 \mathrm{~cm}^{3}\right)$ for pollen analysis were prepared with chemicals $(\mathrm{HCl}, \mathrm{KOH}, \mathrm{HF}$ and acetolysis; Moore et al., 1991) and physical treatment (sieving at $500 \mu \mathrm{m}$ and decanting). Lycopodium tablets (Stockmarr, 1971) were added to sediment samples before preparation for estimation of pollen concentrations. A sum of at least 600 pollen grains was counted, excluding aquatic plants and spores, at a standard magnification of $\times 400$. Pollen of trees, shrubs, herbs, and xerophytes were included in the pollen sum (excluding aquatics and spores). Higher magnifications $(\times 630$ and $\times 1000)$ were used for difficult determinations. Pollen grains were identified using keys and pollen atlases (Moore et al., 1991; Reille, 1992-1998; Punt and Blackmore, 1976-1995; Beug, 2004) and the reference collection of the C.N.R.-I.D.P.A. (Consiglio Nazionale delle Ricerche-Istituto per la Dinamica dei Processi Ambientali) of Milan and of the Institute of Plant Sciences of the University of Bern. The identification of fossil stomata follows Trautmann (1953). Pollen diagrams were drawn using TILIA 1.12 and TiliaGraph. The results are presented as TgView 2.0.2 pollen diagrams (Grimm, 1992-2005). Zonation of pollen assemblages was made by using the program ZONE 1.2 and selecting the 
optimal-sum-of-square partition (Birks and Gordon, 1985). Statistically significant pollen zone limits (SPZL) were determined by using the broken-stick model (Bennett, 1996). In addition, "subzones" as defined by ZONE (for details see Birks and Gordon, 1985) have been set if necessary for the diagram's discussion. In our case, this quantitative determination provides boundaries corre-

a

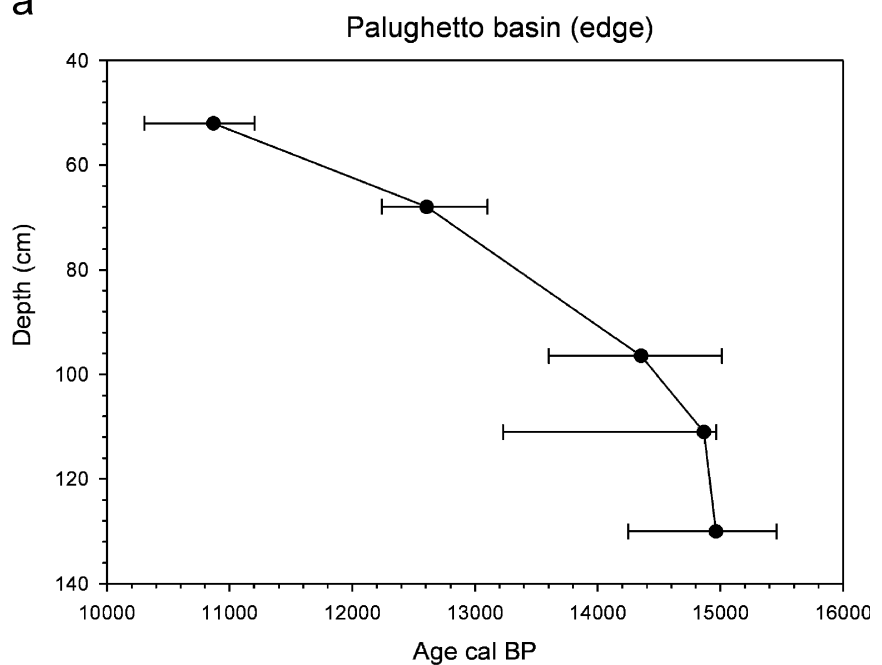

b

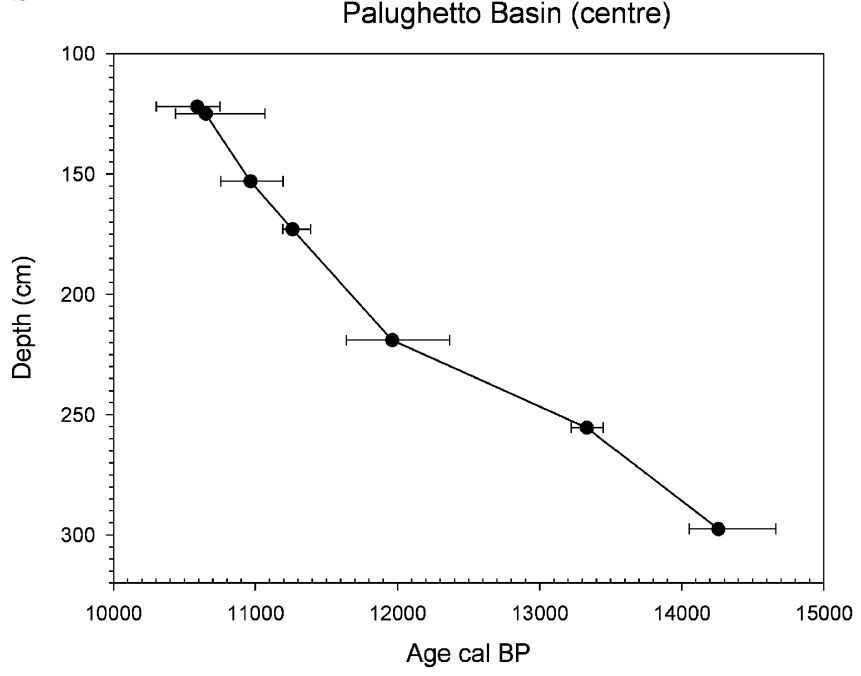

Fig. 3. Depth-age models based on linear interpolation of calibrated radiocarbon years BP: (a) from the edge part of the Palughetto basin (PLE) and (b) from the central part (PLC) of the basin. The dots represent the calibrated median ages and the bars the $95 \%$ confidence intervals according to CALIB 5.0.1 (Reimer et al., 2004). sponding to a conventional zonation on the basis of visual inspection. Usually such subjective zones are built by grouping the main changes in the abundance of the main taxa (see Maher, 1993; Salvador, 1994). The main advantage of using quantitative zonation, however, is that it provides objective, statistically significant zone boundaries across all records of interest. The depth-age models of the two Palughetto records (Fig. 3a and b) are based on linear interpolation between the medians of calibrated ${ }^{14} \mathrm{C}$ ages according to the program CALIB 5.0.1 (Reimer et al., 2004, Tables 2 and 3).

To permit a better comparison between the results from the Palughetto mire and existing pollen stratigraphies from the southern side of the Alps (i.e. Lago di Origlio, Lago di Annone, Pian di Gembro, Lago Piccolo di Avigliana), we re-calibrated the radiocarbon dates of four key records (Lago di Origlio, Lago di Annone, Pian di Gembro, and Lago Piccolo di Avigliana) that possess AMS dates on terrestrial macrofossils (CALIB 5.01). For these sites we established new depth-age models (linear interpolation between medians of calibrated ages) and defined new pollen zones (program ZONE, B-STICK model) following the same procedures chosen for the Palughetto cores. The original subjective zonations of the sites can be consulted in the original publications (e.g. Wick, 1996; Tinner et al., 1999; Pini, 2002; Finsinger et al., 2006).

\section{Results and interpretation}

\subsection{Lithostratigraphy}

The lithostratigraphy of the two new records of Palughetto (PLE and PLC), summarized in Table 4a and b, shows that the sediments were deposited in aquatic or wetland environments (e.g. silt, gyttja, peat). Sediments of the PLC stratigraphy (centre of the basin) reveal changes between lacustrine and mire environments, while the PLE lithostratigraphy indicates that the edge of the basin has been a mire throughout almost the entire period of interest.

\subsection{Chronology and sediment accumulation rates}

Five conventional radiocarbon dates were obtained from charcoal, terrestrial plant remains, and bulk peat from the edge of the Palughetto basin (PLE) (Table 2). Seven samples of uncharred terrestrial plant macrofossils from the central part of the Palughetto basin (PLC) were

Table 2

Conventional radiocarbon dates from Palughetto: edge of the Palughetto Basin

\begin{tabular}{|c|c|c|c|c|c|c|}
\hline Lab no. & Depth (cm) & Analysed fraction & $\delta^{13} \mathrm{C} \%$ & ${ }^{14} \mathrm{C}$ yrs BP & Cal age $\mathrm{BP}(2 \sigma$ range $)$ & Age in diagram \\
\hline H-4755 & $67-69$ & Peat & & $10,795 \pm 165$ & $12,241-13,102$ & 12,608 \\
\hline Gx-21230 & 111 & Cones of Picea abies & -25.2 & $12,000 \pm 340$ & $13,228-14,966$ & 14,865 \\
\hline H-2148 & 130 & Cones of Pinus mugo & & $12,720 \pm 160$ & $14,248-15,459$ & 14,964 \\
\hline
\end{tabular}


Table 3

AMS-radiocarbon dates from Palughetto: central part of the Palughetto Basin

\begin{tabular}{|c|c|c|c|c|c|c|}
\hline Lab nr & Depth $(\mathrm{cm})$ & Analysed fraction & $\delta^{13} \mathrm{C} \%$ & ${ }^{14} \mathrm{C}$ yrs BP & Age Cal BP ( $2 \sigma$ range $)$ & Age in diagram \\
\hline Ua-20966 & 122 & Twig of Picea abies & -26.4 & $9360 \pm 65$ & $10,302-10,750$ & 10,590 \\
\hline Ua-20965 & 125 & Nut of Corylus & -26.5 & $9420 \pm 65$ & $10,438-11,067$ & 10,650 \\
\hline Ua-20968 & 153 & Conifer needles & -27.7 & $9630 \pm 70$ & $10,755-11,194$ & 10,966 \\
\hline Poz-9932 & 173 & Picea needles, shrub twig & & $9850 \pm 50$ & $11,191-11,389$ & 11,260 \\
\hline Ua-20969 & 219 & Cone of Larix & -23.1 & $10,240 \pm 75$ & $11,641-12,367$ & 11,963 \\
\hline Poz-9865 & $255-256$ & Larix needles & & $11,490 \pm 60$ & $13,223-13,450$ & 13,333 \\
\hline Poz-9866 & $297-298$ & Larix needles & & $12,340 \pm 50$ & $14,053-14,663$ & 14,258 \\
\hline
\end{tabular}

Table 4

The sediments (a) from the edge part of the Palughetto Basin (PLE) and (b) from the central (PLC) part of the basin

\begin{tabular}{|c|c|}
\hline $\begin{array}{l}\text { Depth } \\
(\mathrm{cm})\end{array}$ & Sediment \\
\hline \multicolumn{2}{|l|}{ (a) PLE } \\
\hline $49-46$ & Hydromorphic soil with human artefacts \\
\hline $52-49$ & Cyperaceae peat \\
\hline $98-52$ & Forest peat with trunks, in situ stumps and woody material \\
\hline $110-98$ & Gyttja with Larix-litter and Picea-Larix macrofossils \\
\hline $260-110$ & Silty clay to clay with sandy layers and clayey silt \\
\hline \multicolumn{2}{|l|}{ (b) $P L C$} \\
\hline $96-60$ & Forest peat with Abies and Fagus macroremains \\
\hline $116-96$ & Peat with needles, twigs and sporadic cones of Picea and Abies \\
\hline $150-116$ & Peat with needles, twigs and sporadic cones of Picea \\
\hline $180-150$ & Gyttja or decomposed peat with needles \\
\hline $240-180$ & Peat \\
\hline $290-240$ & Gyttja with Larix needles \\
\hline $300-290$ & Peat with Larix needles \\
\hline $350-300$ & Silty gyttja \\
\hline $370-350$ & Laminated silty-clay and clay alternations \\
\hline
\end{tabular}

radiocarbon dated by AMS (Table 3). The linear depth-age models (Fig. 3) are different; we explain this by the different depositional and taphonomical processes acting on the two sites (see Section 4.3). The average sedimentaccumulation rate of the minerogenic sediments (PLE, Figs. 3 and $4,130-110 \mathrm{~cm}: 0.54 \mathrm{~mm} / \mathrm{yr}$ ) is higher than that of the organic deposits (PLE, Figs. 3 and $4,110-55 \mathrm{~cm}$, $0.14 \mathrm{~mm} / \mathrm{yr}$ ), and the (forest) peat accumulated faster in the centre of the basin (Fig. 3b, PLC 219-298 cm $0.34 \mathrm{~mm} / \mathrm{yr}$ ) than at the edge $(0.14 \mathrm{~mm} / \mathrm{yr})$. The transition from Lateglacial to Holocene led to an increase in peat accumulation rate in the centre of the basin, but not on the border, where the Preboreal peat was compacted and then interrupted by the Late Paleolithic human settlement. Water-table variations account for such strong differences in sedimentation rate between sites (Avigliano et al., 2000). However, no evidence of a major hiatus is apparent before the human occupation (e.g. 10,800 cal yr BP).

\subsection{Lateglacial vegetation history at Palughetto}

Two pollen diagrams depicting selected taxa from the edge (PLE) and the central part (PLC) of the Palughetto basin are shown in Figs. 4 and 5. Only the basal parts of the sequences, i.e. the period older than ca 10,800 $10,500 \mathrm{cal} \mathrm{yr} \mathrm{BP}$, are presented here. The pollen records can be subdivided into three and four statistically significant local pollen assemblages zones (PLE 1-3, PLC $1-4)$, respectively. Since the top of the PLE record ends before that of PLC, the youngest zone (PLC-4) could only be delimited in the PLC record. Its onset, however, is suggested in the topmost samples of the PLE record $(53 \mathrm{~cm})$.

Initially, the pollen records indicate a vegetation typical of cold and steppic environments (PLC-1 and PLE-1). Light-demanding and pioneer herbaceous taxa (Artemisia, Chenopodiaceae, Gramineae, Asteroideae, Rubiaceae, Cichorioideae, etc.) were present together with shrubs and chamaephytes (Ephedra fragilis, Ephedra distachya, Helianthemum, Hippophaë; the last may also originate from lower altitudes). High percentages of pollen of Pinus sylvestris/mugo were present from $>15,500$ cal yr BP, but the absence of stomata (PLC-1a, basal part of PLE-1) suggests transport of pollen from areas at lower elevation. This phase with high pine pollen percentages was interrupted by a short and abrupt increase in xerophytes during subzone PLC-1b. This percentage rise mainly reflects pollen of Artemisia, which reaches at least $40 \%$, and to a lesser extent to the increase of pollen of Chenopodiaceae and other herbs such as Anthemis-t. and Cichorioideae. This change was accompanied by a decline of pollen of arboreal taxa such as P. sylvestris/mugo and Betula, but not Juniperus. Similar pollen changes are also recorded at other sites (Gola di Lago, Zoller and Kleiber, 1971; Pian di Gembro, Pini, 2002; Lago di Lavarone, Arpenti et al., unpublished) and may reflect a brief opening of the forests at lower altitude, possibly induced by a transient climatic cooling. The subsequent phase (see PLC1c) is again characterized by high values of $P$. sylvestris/ mugo pollen, with the presence of stomata that suggest the local presence of the taxon at ca 14,600-14,500 cal yr BP according to the central-core chronology. Differences in stomata content among the two cores PLC/PLE are best explained by different taphonomic processes. Stomata are contained in needles and released only during decompositional processes or sample preparation. If the macrofossils are well preserved, stomata finds in the pollen slides may be small or completely lacking since the sediment samples 


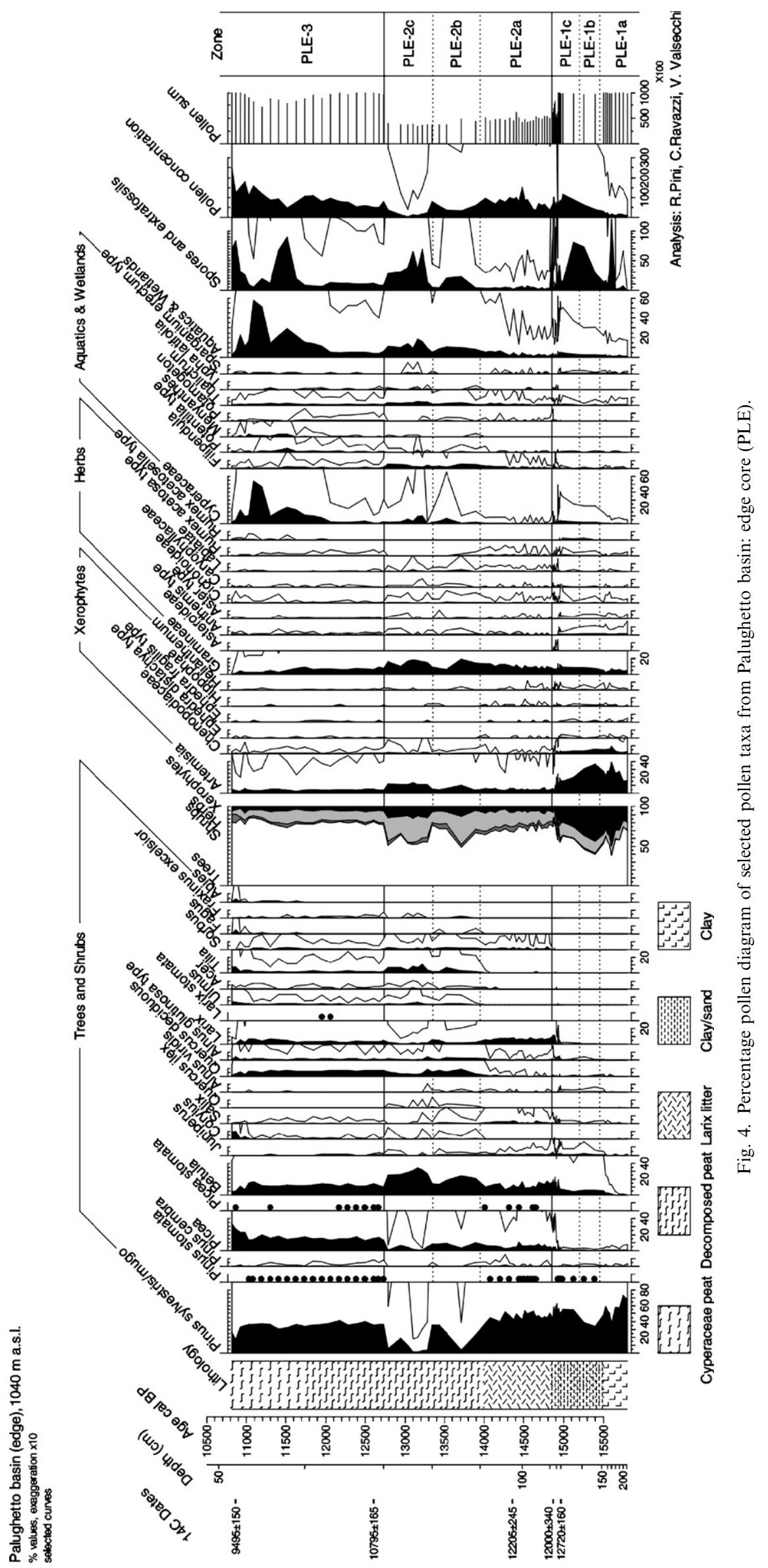




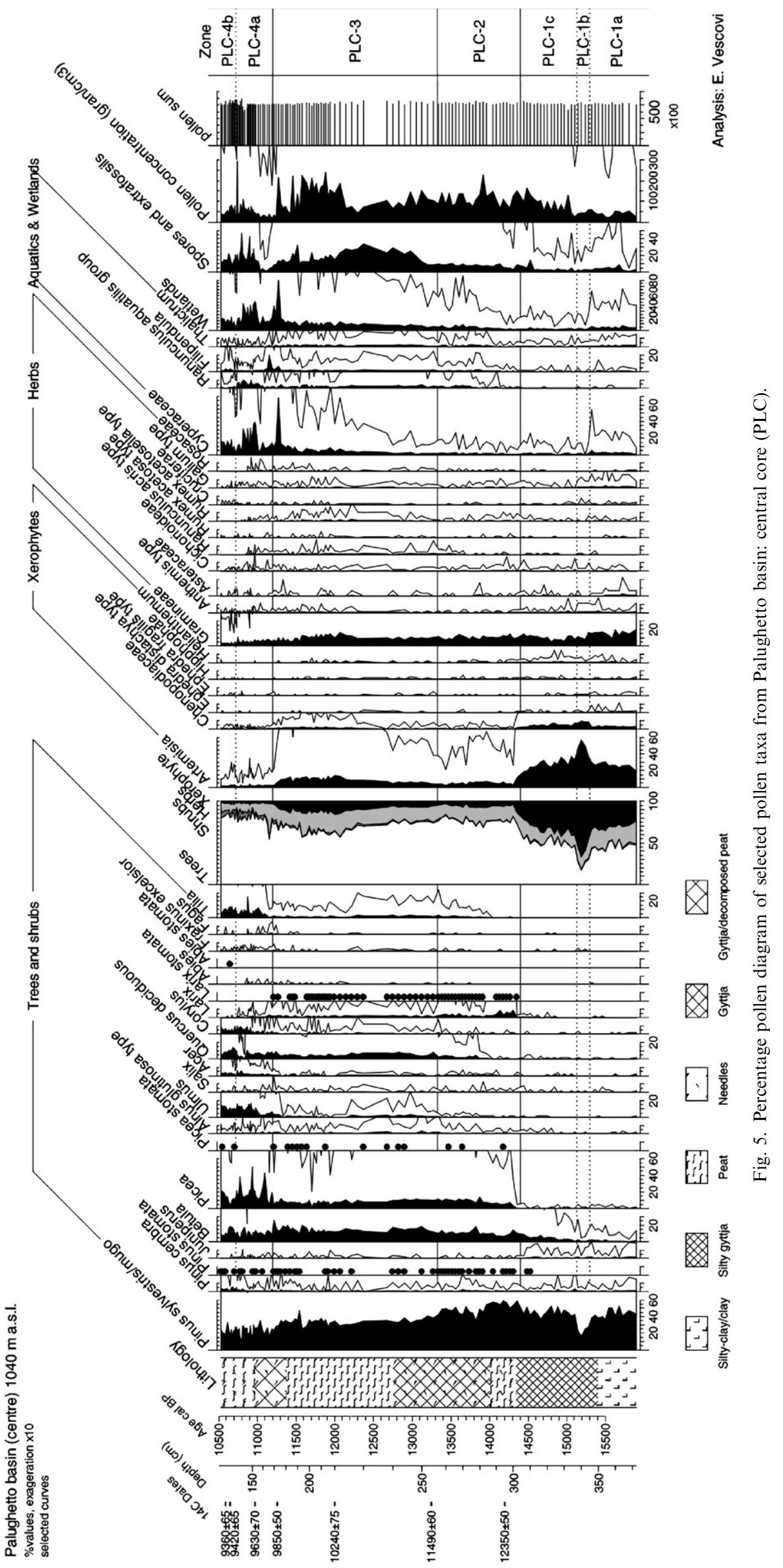


used for pollen preparation are sieved and thus do not contain particles larger than $>0.5 \mathrm{~mm}$ that could release stomata. The edge stratigraphy shows that Pinus stomata were present already before, at ca 15,300-15,200 cal yr BP at the transition from PLE-1b to PLE-1c, shortly followed by $P$. mugo cones at the beginning of PLE-1c (Avigliano et al., 2000). This evidence proves the local occurrence of $P$. mugo stands at Palughetto. However, in both stratigraphies the arboreal pollen percentages are too low to infer closed forest conditions (25-70\%), and no tree macrofossils are recorded throughout pollen zones PLC-1 and PLE-1. We therefore suggest that before 14,800-14,400 cal yr BP P. mugo (ssp. mugo) shrubs were established at the elevation of Palughetto, probably just above the treeline. The development of a $P$. mugo (ssp. mugo)-belt above the treeline is a characteristic shared in the Eastern Alps, the Carpathians, and the Balkanic ranges during the last 15,000 years (Bozilova \& Tonkov, 2000; Schmidt et al., 2000; Björkman et al., 2002). However, the role of $P$. mugo in the early stages of the Lateglacial colonization of mountain belts is probably underestimated in pollen studies due to the difficulty distinguishing its pollen from $P$. sylvestris. The steady pollen increase and the macrofossil record of Betula suggest the regional expansion of this tree at ca 15,000 cal yr BP.

Pollen and stomata data suggest that during the subsequent phase (PLC-2, PLE-2) Pinus, Betula, Picea, and Larix formed subalpine forests and scrub stands on the Cansiglio Plateau. The beginning of this afforestation phase is fixed by the beginning of the zone boundary (SPLZ) PLC/E-1 to PLC/E-2 and is dated at 14,800 and 14,400 cal yr BP in the PLE and PLC records, respectively. The low percentages of Juniperus, Artemisia, Chenopodiaceae, and Helianthemum pollen after 14,800-14,400 cal yr $\mathrm{BP}$ suggests that the expansion of forests and shrubland at higher altitudes was connected with a decline of steppe and of Juniperus heaths ( $J$. nana dwarf heaths according to the modern ecology of the subalpine regional vegetation). Regular and continuous records of pollen of thermophilous taxa suggest that Quercus, Ulmus, Alnus, and Tilia were present after ca $14,000 \mathrm{cal}$ yr BP near the site, probably at lower altitude and in low numbers. In agreement with pollen data, trunks, in situ stumps, and high quantities of woody material, branches, cones, and other megafossils unambiguously document that coniferous forests were present on the edge of the basin (Avigliano et al., 2000). Picea, Larix, and Betula megafossils occurred since ca 14,000 cal yr BP, but trunks and stumps are concentrated at $13,500-13,000$ cal yr BP, stratigraphically corresponding to the subzone boundary between PLE-2b and PLE-2c. The considerable differences between the two biostratigraphies (PLC and PLE) in regard to major pollen types such as P. sylvestris, Betula, or Artemisia and Gramineae are probably due to local taphonomic processes. If compared with other diagrams of the southern side of the Alps from this altitudinal belt (800-1400 m, e.g. Gola di Lago, Zoller and Kleiber, 1971; Pian di Gembro, Pini, 2002) the central core is more representative of regional vegetation history, whereas the edge core shows rather unique features that probably reflect local depositional conditions (Fig. 4). This particularly concerns the strong decline of coniferous pollen ( $P$. sylvestris/mugo, Larix, Picea) at $14,000-12,800$ cal yr BP, which are also clearly reflected in the Pinus stomata frequencies and in a drop of total pollen concentration (PLE-2b and c). The deposit consists of an accumulation of wood, including stumps. This suggests a collapse of the in situ Larix-Picea-Pinus stands in the edge core site, possibly as a result of a rising water table and associated water logging. The strong declines of pollen and stomata of late-successional Larix, Pinus and Picea probably reflect the local collapse of these stands (as documented by the huge amount of megafossils of these trees found in the sediment). The percentage increase of Betula and thermophilous trees such as Tilia and Ulmus in PLE- $2 b$ and $c$ does not appear in the concentration values; so it is regarded as a percentage calculation artefact caused by the decrease in pine pollen. We assume that the two subzones PLE-2b and $\mathrm{c}$ were strongly affected by such local processes.

Although vegetation remained rather stable until 13,300 cal yr BP (zone boundary PLC-2 to -3 ), pollen of xerophytes (Artemisia, Chenopodiaceae) and of thermophilous trees increased gradually. Subsequent pollen data suggest a long-lasting Pinus decline connected with a gradual opening of forests, both culminating at ca 12,100 cal yr BP. However, both stratigraphies indicate that subalpine forests were still closed at this time and dominated by coniferous trees, as inferred from Picea and Larix cones in zone PLE-2 (Avigliano et al., 2000 and unpublished data) and by Pinus stomata around 12,100 ca$1 \mathrm{yr}$ BP in PLC-2. The younger part of zone PLC-3 chronologically correspond approximately to the pronounced cooling of the YD (12,650-11,500 cal yr BP, see Ammann et al., 2000), which had strong effects on vegetation in the southern side of the Alps and elsewhere in Europe (e.g. Lotter, 1999; Litt et al., 2001; Finsinger et al., 2006). Other investigations from the southern side of the Alps suggest that this period can be subdivided into three parts (Lago di Annone, Wick, 1996), but in our pollen series of PLC only one major phase is clearly detectable, i.e. the climatic cooling at the beginning of the YD (ca 12,500 calyr BP), which mainly affected the thermophilous trees and shrubs such as Quercus, Alnus, Ulmus, Tilia, and Corylus (at around 12,300 cal yr BP). In the PLE record the beginning of the YD is not clearly reflected in the pollen, probably due to local taphonomic processes as documented in the previous zone (PLE-2). However, in agreement with other records from the Southern Alps, the increase of pollen of Artemisia (15\%) and other steppic and alpine herbs in the PLC core suggests a regional expansion of steppe and meadow vegetation during the climatic cooling. At the end of the YD (ca 11,500 cal yr BP), increasing pollen percentages of Quercus, Tilia, Ulmus, and Picea, combined with a gradual decrease 


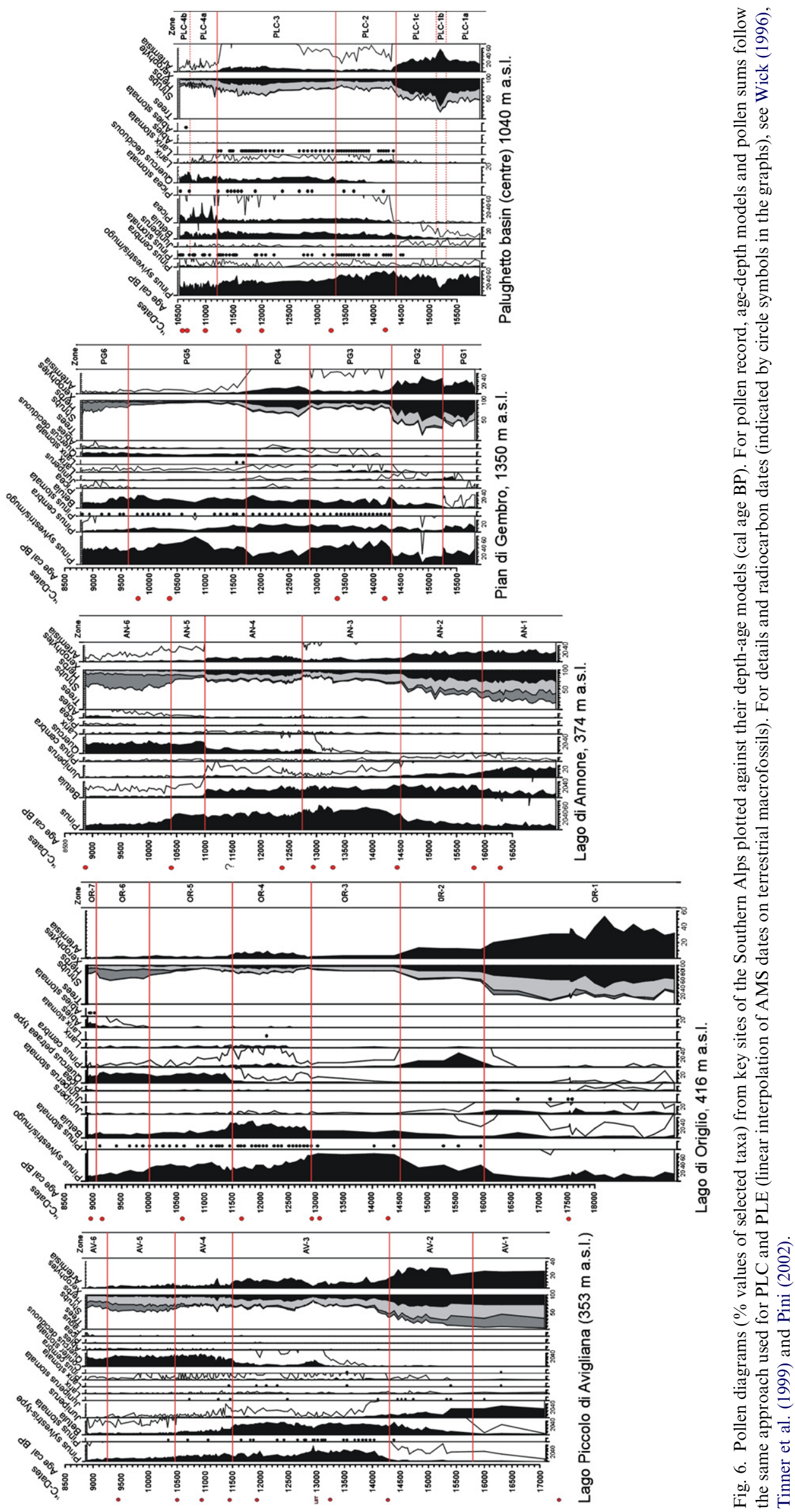


of Artemisia and other light-demanding herbs and chamaephytes point to a recovery of deciduous thermophilous trees as a consequence of the climatic warming at the Lateglacial/Holocene transition.

The subsequent zone (PLC-4, 11,200-10,500 cal yr BP) falls into the early Holocene. However, due to the chronological uncertainties in the PLC and PLE depthage models (Table 2, see 2 sigma age ranges) it is difficult to assess whether the marked vegetation change that delimits the statistically significant pollen zone boundary at $11,300-11,200$ cal yr BP is coeval with the beginning of the Holocene at ca $11,550 \mathrm{cal} \mathrm{yr}$ BP. In the pollen diagram of the central part of the basin (PLC), an increase of thermophilous trees and a decrease of Betula, Pinus, Juniperus, Artemisia, and other herbs shows that the subalpine coniferous forests were partly replaced by mixed deciduous forests of Quercus, Tilia, Ulmus, and Acer in response to the climatic warming of the early Holocene. In contrast to Betula and P. sylvestris/mugo, P. abies was able to expand together with the thermophilous deciduous taxa, suggesting that a mountain mixed forest belt developed at Palughetto during the early Holocene that has no modern natural analogue.

The comparison between the PLC and PLE records shows that care should be taken when interpreting stratigraphically disturbed pollen series such as those from the basin edge site of PLE, especially if the goal is to reconstruct extra-local vegetation history. The centre of a basin usually provides the most complete sedimentary sequence (Wright, 1991), whereas cores near the basin edge may record gaps in sedimentation or strongly changing accumulation rates, yet be rich in macrofossils. In this sense, the sequence PLE, though affected by non-site representative local sedimentary processes (see Moore et al., 1991), is nevertheless useful for our reconstruction because it testifies the very early high-altitudinal presence of trees and shrubs such as $P$. abies and $P$. mugo ssp. mugo through the presence of in situ megafossils, macrofossils and stomata (as a proxy for macrofossils).

\subsection{Zonation results of the selected key sites}

The results of quantitative zonation of the five sites in a transect across the Southern Alps (Fig. 1) vary across the different records (Fig. 6), but some SPZLs have similar ages at all (e.g. 14,500-14,400 cal yr BP) or at least at most sites (e.g. 16,000-15,800, 12,900-12,700, 11,500-11,200 cal yr BP). Moreover, sites with similar altitudinal positions show similar pollen-inferred vegetational histories. For instance, the pollen records suggest that afforestation started at ca 16,000 cal yr BP at the lowland sites (Avigliana SPZL AV 1-2, Origlio SPZL OR 1-2, Annone SPZL AN 1$2)$, but began later at the mountain sites $(14,500 \mathrm{cal}$ yr BP, Pian di Gembro, SPZL PG2/3). Similarly, the initial expansion of Quercus (and other thermophilous trees) began at ca $13,000 \mathrm{calyr} \mathrm{BP}$ at all lowland sites, was followed by a decline during the $\mathrm{YD}$, and finally reached its maximum several millennia later during the early Holocene (Fig. 6).

\section{Discussion}

The pollen diagram from the centre of the Palughetto basin (PLC) shows conspicuous oscillations related to extra-local vegetational change. Statistically significant pollen zone boundaries (SPZL) are located at $14,800-14,400$ cal yr BP, 13,300, and 11,200 cal yr BP (see Figs. 4 and 5, Tables 2 and 3 for 95\% confidence intervals of calibrated ages) and delimit periods of major vegetation change in the Palughetto area. These patterns are consistent with previous studies from the Southern Alpine area (e.g. Wick, 1996; Tinner et al., 1999; Pini, 2002; Finsinger et al., 2006, see Fig. 6). Since these shifts have specific time-inherent features, we examine the palaeoecological and palaeoclimatic implications for each of these single steps according to their chronostratigraphical order.

\subsection{Alpine deglaciation and vegetational and climatic processes between 18,000 and 14,500 calyr BP}

The recession of glaciers from the amphitheatres in the Southern Alpine foreland started before ca $18,000 \mathrm{cal} \mathrm{yr}$ $\mathrm{BP}$, as shown by the oldest AMS-dates of terrestrial plant macrofossils from pre-alpine lowland lakes located within the moraines of the last glaciation. At Lago di Origlio, which is situated ca $200 \mathrm{~m}$ above and $30 \mathrm{~km}$ north of the nearest glacial amphitheatre, a sediment change from silty and sandy layers to silty gyttja is dated at ca $17,500 \mathrm{cal}$ yr BP (AMS-dated twig). Between local deglaciation (recorded by till at the base of the core) and the level dated to $17,500 \mathrm{calyr}$ BP, more than $4 \mathrm{~m}$ of silty and clayey sediments accumulated, suggesting a deglaciation age earlier than 18,000 cal yr BP for this site (Tinner et al., 1999). The sediment change at $17,500 \mathrm{calyr}$ BP was associated with an expansion of shrubs (Juniperus stomata occur regularly) in the herb-dominated steppe tundra. A new AMS-date from a wood macrofossil from Lago Piccolo di Avigliana provides a calibrated age of ca 18,275 cal yr BP (Finsinger et al., pers. comm. data not shown here). The wood was found below the first macrofossil finding of tree Betula fruits (3 occurrences), but above the oldest Larix needle (one occurrence), suggesting that at this time open Larix stands had already established on the area that had become ice-free after the deglaciation of the outer part of the Avigliana amphitheatre. Below the level of this date, ca $6 \mathrm{~m}$ of silty and clayey sediments were deposited in the lake, indicating that deglaciation at Avigliana most likely occurred before 18,000-18,500 cal yr BP. A deglaciation pulse at ca $18,100-17,020$ cal yr BP is also indicated by open Larix forests growing at the Fornaci di Revine, within the morainic amphitheatre of Vittorio Veneto (Ventian Pre-Alps). The Larix stand was buried by colluvial deposits interfingering with lacustrine sediments, 
possibly in relation to deglaciation processes (Casadoro et al., 1976; Kromer et al., 1998; Friedrich et al., 1999). These results are in agreement with studies from Lago di Lugano (Niessen and Kelts, 1989) and from Zürichsee (Lister, 1988). On the basis of radiocarbon-dated lithological evidence (top of glacial silt rhythmites AMS-radiocarbon dated at ca 17,600 cal yr BP) Lister (1988) showed that alpine glaciers had retreated from Zürichsee at about 18,000 cal yr BP. Niessen and Kelts (1989) were able to correlate magnetic records from Lago di Lugano with Zürichsee and suggested that deglaciation processes had a similar age all over the Alps and that the amphitheatres were ice-free by 18,000 cal yr BP. The last rapid deglaciation pulse from the glacial amphitheatres of Lago di Lugano and Zürichsee occurred at ca 17,500 cal yr BP, in close agreement with our lowland lacustrine records (e.g. Lago di Origlio and Lago Piccolo di Avigliana, Tinner et al., 1999; Finsinger et al., 2006).

Evidence of climatic change from an oxygen-isotope record is available from the southeastern side of the Alps (Lago di Ragogna, Fig. 1). The record indicates a climatic warming at around $17,500 \mathrm{calyr} \mathrm{BP}$ connected to the expansion of Larix and Pinus cembra trees (Wick, 2004). Given the close connection between the Alpine-Central European and Greenland climatic histories (von Grafenstein et al., 1999, 2000; Schwander et al., 2000; Heiri and Millet, 2005) during the Lateglacial, the climatic warming at 17,500 calyr BP may correspond to the positive excursion in the oxygen isotopes of the GRIP ice-core at ca $17,500-17,000 \mathrm{cal}$ yr BP (maximum values in the younger half of GS-2b, Björck et al., 1998). Despite the fact that Alpine glaciers reached the lowland edges of the Po-Plain during the LGM (Orombelli et al., 2004) at ca 22,000 cal $\mathrm{BP}$, the presence of woody taxa seems most likely for sheltered sites in the Po-Plain (e.g. Lago della Costa, Colli Euganei, Kaltenrieder et al., 2004), even during the coldest periods of the LGM (ca 22,000 cal yr BP according to the GRIP record). Such tree taxa included $P$. sylvestris, Larix, and tree Betula, in the entire South-Alpine foreland, P. mugo and Picea in the eastern Pre-Alps, but possibly also more thermophilous trees such as Fagus in the Colli Euganei, a sheltered hilly area in the Po Plain (Kaltenrieder et al., 2004).

However, the well-dated records of pollen, stomata, and/ or macrofossils at Lago Piccolo di Avigliana, Lago di Annone, and Lago di Origlio suggest that the formation of rather closed forests (e.g. Origlio) or open woodlands (e.g. Avigliana) did not occur before about 16,000-15,800 cal yr $\mathrm{BP}$ in the western part of the Italian foreland. In the Ticino region (Italy and Switzerland) these early forests were dominated by $P$. cembra and later also by $P$. sylvestris and Betula (pollen, stomata, and macrofossil records from Lago di Ganna, Lago di Origlio, and Balladrum, see Schneider and Tobolski, 1985; Tinner et al., 1999; Hofstetter et al., 2006). In contrast, open forests were dominated by Betula and Larix in the Torino region (pollen and macrofossil evidence, Finsinger et al., 2006) and by Betula, Larix, and P. cembra in the Brianza region (pollen and macrofossil evidence, Wick, 1996). In the forelands of the Southeastern Alps, P. cembra, P. mugo, and Larix decidua were important during the early afforestation (e.g. Lago di Ragogna, Monegato et al., accepted), whereas $L$. decidua and $P$. sylvestris formed early woods at Fornaci di Revine (Friedrich et al., 1999). The observed regional differences may be related to soil and bedrock variability (Hofstetter et al., 2006). However, the establishment and persistence of these lowland forests during the period $16,000-14,500 \mathrm{cal}$ yr BP suggest rather stable environmental conditions at low elevations. Afforestation processes at 16,000 cal yr BP were probably related to climatic warming at 16,000 cal yr BP. To our knowledge, no non-pollen evidence exists for such a climatic change in continental Europe. However, such an event is in good agreement with high-resolution palaeoecological, isotopic, and sedimentologic data from European North Atlantic cores and elsewhere. These records indicate a strong climatic warming at 16,000 cal yr BP, which is hardly recorded in the oxygen-isotope series of the Greenland icecores but apparently had a global extent (Lagerklint and Wright, 1999).

At higher altitudes the Palughetto and Pian di Gembro (see Pini, 2002 and Fig. 6) sedimentary records indicate that the mountain belt of the Italian Alps was deglaciated before the Bølling period (onset at 14,700-14,500 cal yr BP, Tables 3 and 5). In agreement with this interpretation, Schneider and Tobolski (1985) have shown that several mountain sites of the Southern Alps (e.g. Suossa at $1700 \mathrm{~m}$ a.s.l., Zoller and Kleiber, 1971 and also Sass de la Golp $1953 \mathrm{~m}$ a.s.l., Burga, 1980) were ice-free before the beginning of the Bølling period. Early deglaciation proceeded by the two combined processes of down melting (in altitudes) and ice-retreat (along the valleys). Since we know that before 14,500 cal yr BP, subalpine forests or open woodlands covered sites below $500 \mathrm{~m}$ (e.g. Lago di Origlio, Balladrum, Avigliana) and those sites at ca $1000 \mathrm{~m}$ a.s.l. were most likely unforested (e.g. Gola di Lago, Pian di Gembro), the treeline must have been located at ca $800-1000 \mathrm{~m}$ a.s.l. However, our new results suggest that in the eastern Pre-Alps $P$. mugo (probably the shrubby subspecies $P$. mugo ssp. mugo) expanded at ca $15,000 \mathrm{cal} \mathrm{yr}$ BP (AMS-dated P. mugo cones, Avigliano et al., 2000) into the alpine meadows above treeline (i.e above ca $800-1100 \mathrm{~m}$ a.s.l). This early expansion may be explained by the occurrence of $P$. mugo at most sites of the eastern alpine forelands (Beug, 1964; Paganelli, 1996; Monegato et al., accepted).

\subsection{Climatic and vegetational changes at ca 14,500 calyr $B P$}

An abrupt change of forest structure and density occurred at 14,800-14,300 cal yr BP, both in the foreland and at higher altitudes. At Lago di Origlio closed P. cembra forests located near treeline collapsed around 14,500 cal yr 
BP, when P. sylvestris and Betula expanded. The collapse of lowland P. cembra stands has also been documented in macrofossil and pollen series from a site near Locarno (Balladrum), where it is dated around 14,250 cal yr BP (Hofstetter et al., 2006). A similar expansion of P. sylvestris into Juniperus-Betula-Pinus lowland parklands is dated at 14,580 calyr BP at Lago di Annone (Fig. 6). Pollen, stomata, and macrofossil data from Lago Piccolo di Avigliana, located ca $175 \mathrm{~km}$ southwest of Annone and $400 \mathrm{~km}$ southwest of Palughetto, demonstrated that $P$. sylvestris expanded into Juniperus-Betula-Larix lowland woods at 14,500 cal yr BP (Finsinger et al., 2006).

In the mountain belt of the Southern Alps, the expansion of Pinus was accompanied by the expansion of other arboreal taxa such as Larix, Picea, and Betula at Palughetto (Figs. 4 and 5, see also stomata curves) and Larix, P. cembra, and Betula at Pian di Gembro $(1350 \mathrm{~m}$ a.s.1.). Similarly, the expansion of $P$. sylvestris-P. cembra-Betula forests in unforested habitats is dated at $14,600 \mathrm{cal}$ yr BP at Gola di Lago, at $970 \mathrm{~m}$ a.s.1. (Zoller and Kleiber, 1971). A recent pollen study (including stomata) at Totenmoos in Val d'Ultimo (1718 $\mathrm{m}$ a.s.l., Heiss et al., 2005) inferred Larix afforestation before 13,700 cal yr BP. In addition, pollen studies from Passo del Tonale (1883 m a.s.l., Gehrig, 1997) show that treeline was below this site before the onset of the Holocene at 11,500 cal yr BP. Therefore, it is likely that in this area treeline reached an upper limit between 1700 and $1900 \mathrm{~m}$ a.s.1. at or shortly after 14,500 cal yr BP. Previous estimates for the Northern Alps and their forelands suggested slightly lower altitudes at this time (Burga and Perret, 1998).

The substitution of treeline forests at the lowland sites as well as the displacement of alpine habitats to higher altitudes probably reflect climatic warming at the beginning of the Bølling-Allerød interstadial period at 14,700 $14,500 \mathrm{cal} y \mathrm{r} \mathrm{BP}$, corresponding in time to the onset the Greenland Interstadial event GI-1e in the Greenland ice cores (Figs. 7 and 8). Between 14,700 and 14,500 cal yr BP (ca 14,500 cal yr BP in GRIP; 14,600 cal yr BP in NGRIP, 14,650 cal yr BP in GISP2; Dansgaard et al., 1993; Grootes et al., 1993; North GRIP Ice Core Project Members, 2004; see Fig. 7) temperatures increased markedly in Greenland and elsewhere in the northern hemisphere (e.g. by about $8-12{ }^{\circ} \mathrm{C}$ in Greenland and $4-6^{\circ} \mathrm{C}$ in Northern and Central Europe; Björck et al., 1998; von Grafenstein et al., 1999; Lowe et al., 2001; Heiri and Millet, 2005), leading to pronounced changes in the biosphere. Oxygen-isotope records on bulk carbonate at the Torbiera di Trana (a site near Torino, Fig. 1; Eicher, 1987) suggest that at the onset of the Bølling period, temperature also increased south of the Alps. The timing of this shift has been constrained to ca 14,500 cal yr BP by the Lago Piccolo di Avigliana $\delta^{18} \mathrm{O}$ record (Finsinger, 2004; Finsinger et al., 2006).

In Central Europe climatic warming at 14,700-14,500 ca$1 \mathrm{yr}$ BP-induced large-scale afforestation (Lotter, 1999; Litt et al., 2001, 2003) involving the expansion of Betula in open shrublands (Salix, Juniperus, Hippophaë). The beginning of

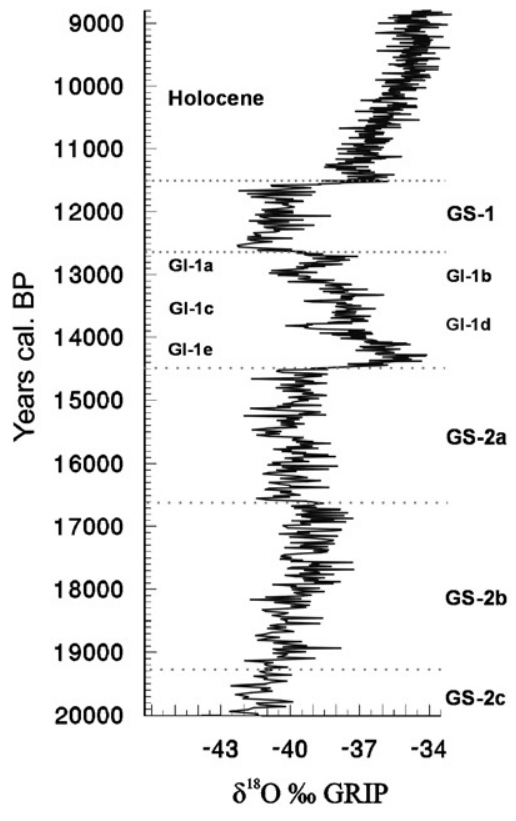

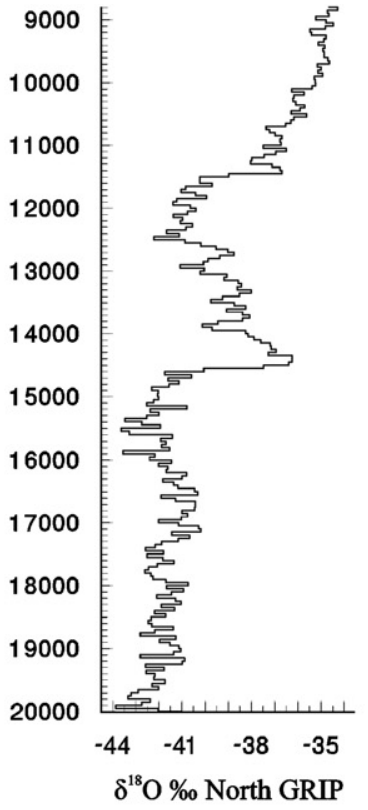
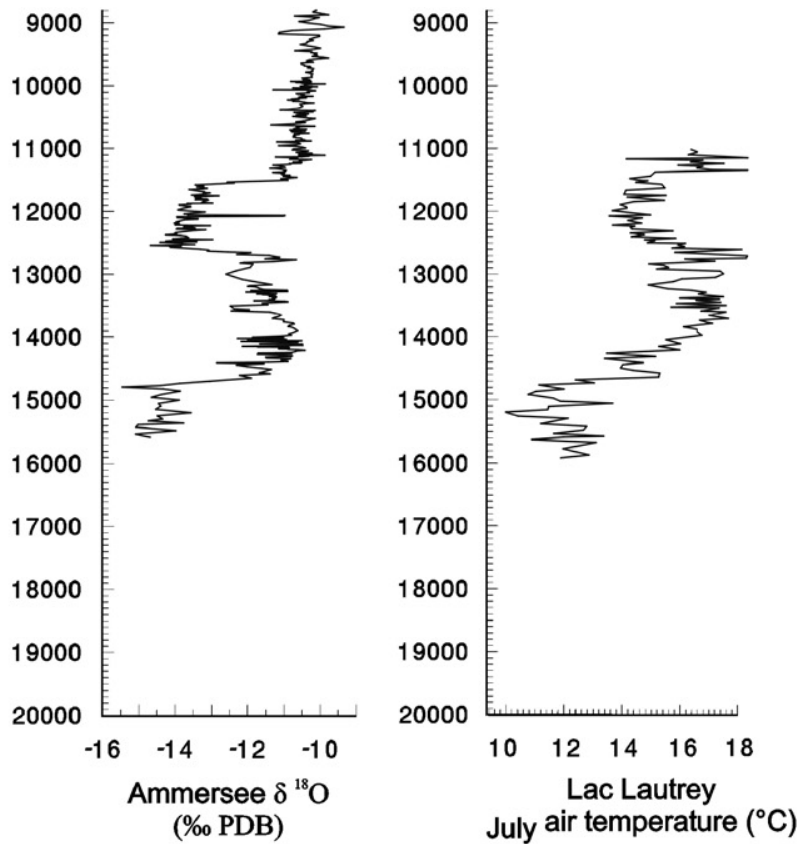

Fig. 7. Comparison of oxygen isotope records from Greenland and Central Europe with chironomid-inferred July air temperatures from the Jura mountains (Northern Alpine forelands). Oxygen isotope ratios in the GRIP and in the NorthGRIP ice cores (Dansgaard et al., 1993; Johnsen et al., 1997; North Greenland Ice Core Project Members, 2004), oxygen isotope ratios measured on ostracodes from Ammersee, southern Germany (von Grafenstein et al., 1999) and chironomid-inferred July air temperature from Lac Lautrey, Jura, France (Heiri and Millet, 2005). The Greenland Interstadial (GI) and Stadial (GS) events follow Johnsen et al. (1992) and Björck et al. (1998). Nomenclature of GRIP climatic phases follows Johnsen et al. (1992) and Björck et al. (1998). GRIP data from National Climatic Data Center-NOAA Satellite and information Service and WDC for Paleoclimatology. 

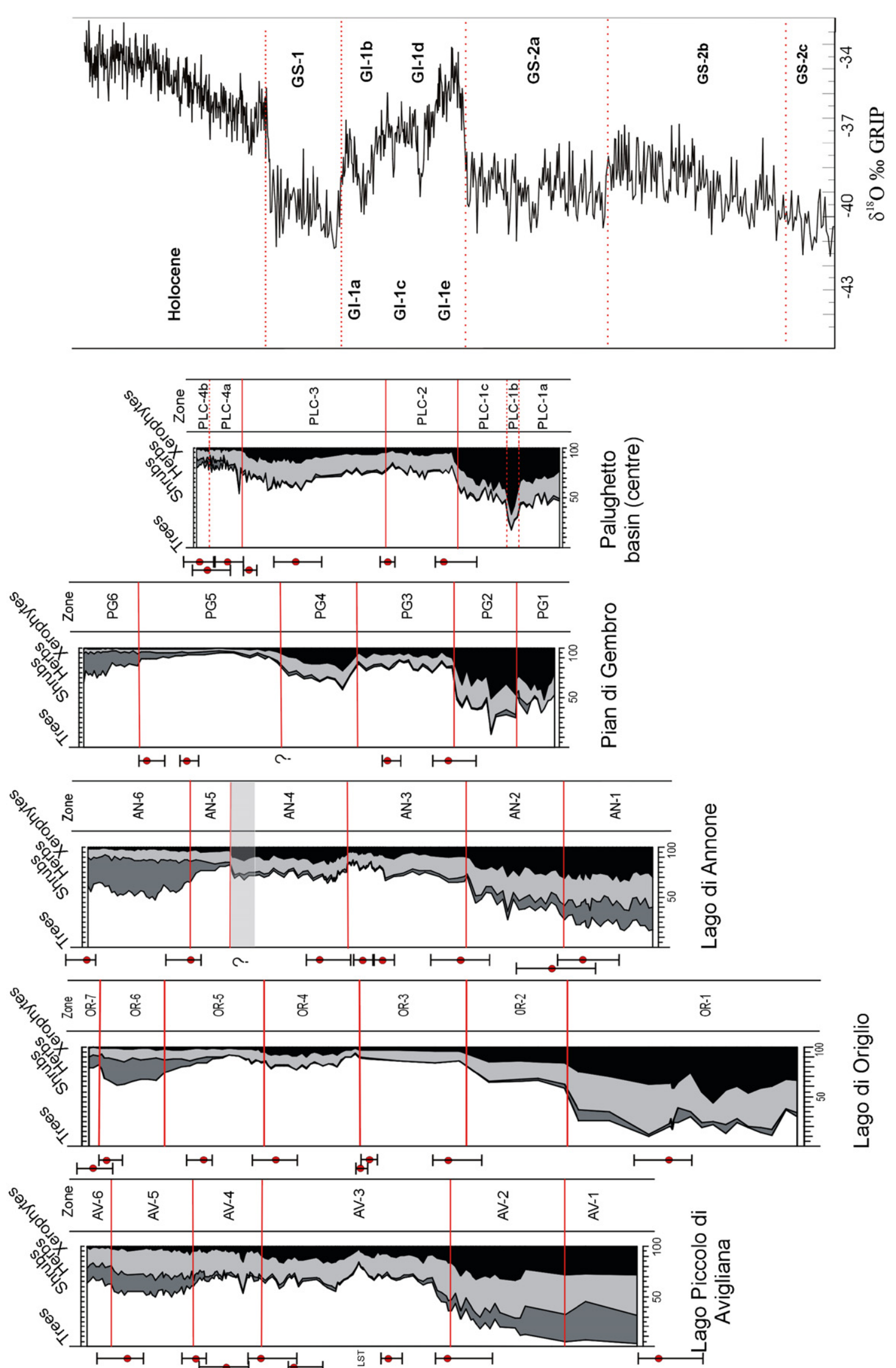

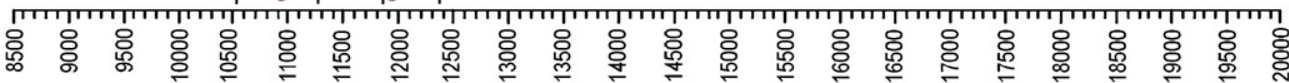




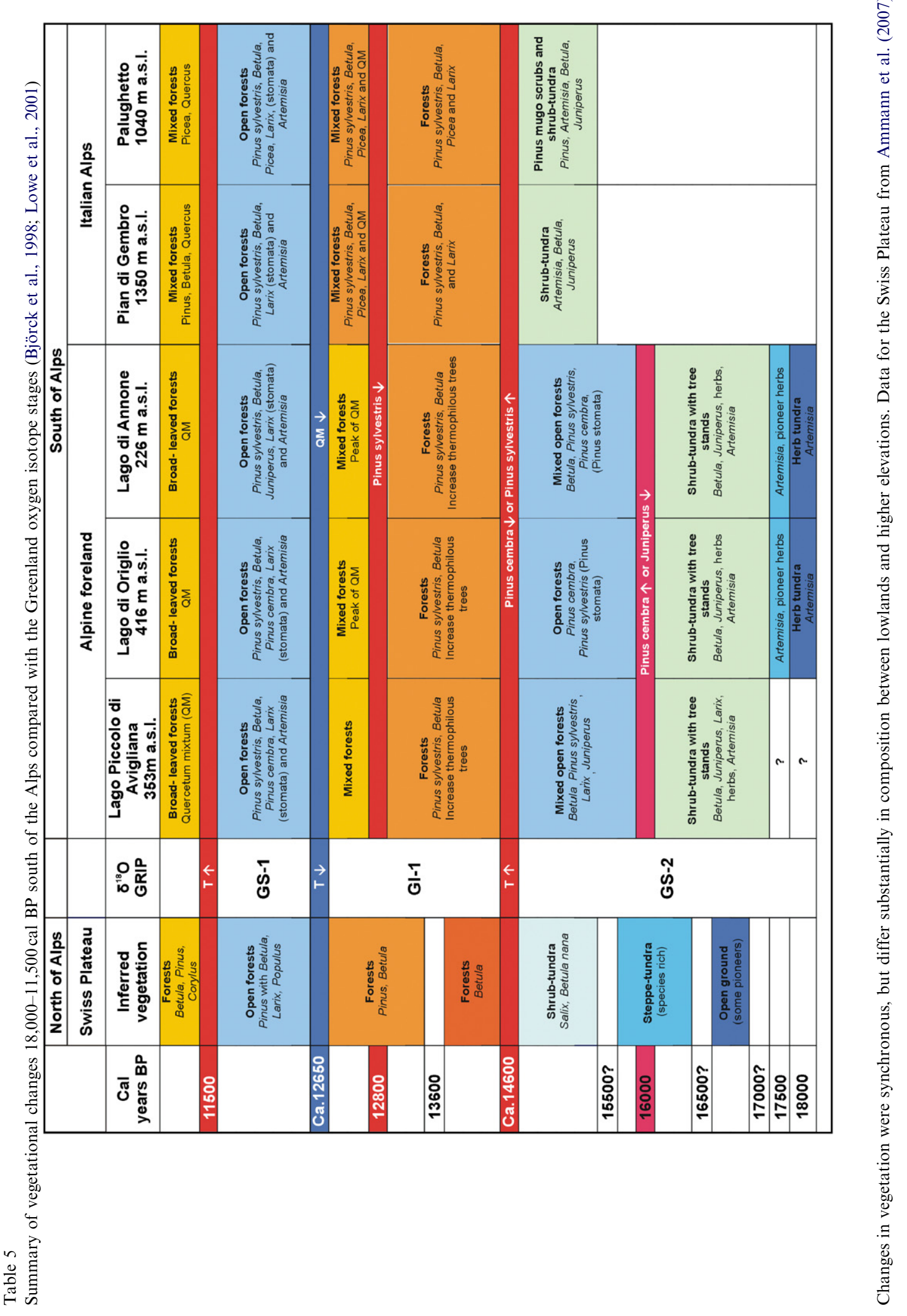


the $P$. sylvestris expansion is dated somewhat later at ca $14,500-14,000$ cal yr BP on the Swiss Plateau and in the Jura Mountains (Tinner et al., 2005; Magny et al., 2006), suggesting that the expansion of Pinus on the northern side of the Alps may have lagged behind the expansion of tree Betula (see Table 5). At Längsee (Austria) P. sylvestris expanded more or less synchronously with the deposition of the Neapolitan Yellow Tephra (NYT, Schmidt et al., 2002), which has an estimated age of $14,120 \mathrm{calyr}$ BP. Unfortunately, this tephra was not found at other sites in the southern side of the Alps, thus preventing the use of stratigraphic correlation based on tephrochronology for this transition.

\subsection{The expansion of mixed oak forest south of the Alps at 13,100-12,600 cal yr BP}

Vegetational change at $13,100-12,800 \mathrm{calyr}$ BP was characterized by the onset of the decline of $P$. sylvestris (and/or less likely $P$. mugo) and the subsequent expansion of herbs and chamaephytes such as Artemisia at most sites across all belts from the lowlands to at least $1400 \mathrm{~m}$. The onset of this change is delimited at Palughetto $(13,300 \mathrm{cal} \mathrm{yr}$ BP), Pian di Gembro (12,900 cal yr BP), Lago di Annone $(12,800 \mathrm{cal} \mathrm{yr} \mathrm{BP})$, and Lago di Origlio (12,900 cal yr BP). A corresponding zone limit at 12,800 cal yr BP (optimalsum-of-square partition) is statistically not significant in the Lago di Avigliana pollen record.

At Lago di Origlio the decline of $P$. sylvestris was accompanied by the increase of Betula pollen (ca $12,800 \mathrm{calyr}$ BP) and later by the increase of $P$. cembra and herb pollen (at 12,600 calyr BP). A short-term expansion of Quercus and other thermophilous taxa such as Tilia and Ulmus occurred between 12,800 and 12,600 cal yr BP (Tinner et al., 1999). These vegetational patterns are similar to those depicted in the pollen record of Lago di Annone, where the onset of the Pinus decline and the expansion of thermophilous taxa is dated at 13,100-13,000 cal yr BP (Wick, 1996). However, at this site and at Lago Piccolo di Avigliana, the expansion of thermophilous taxa was much more pronounced than at Lago di Origlio. The onset of the expansion of thermophilous taxa is dated at ca 13,100 cal yr BP at Lago Piccolo di Avigliana, but here $P$. sylvestris did not decline and herbs did not increase before ca 12,900-12,800 cal yr BP (Finsinger et al., 2006). At Lago Piccolo di Avigliana the local presence of Quercus is unambiguously documented since at least 13,450 cal yr BP by macrofossil finds. In the higher vegetational belt, the decline of $P$. sylvestris/mugo and the increase of herbs expansion is dated at $13,300 \mathrm{cal} \mathrm{yr}$ $\mathrm{BP}$ at Palughetto and at 12,900 cal yr BP at Pian di Gembro (Pini, 2002). However, only at Palughetto these vegetation changes were connected to noticeable increases of pollen of thermophilous tree taxa, which were most probably produced by plants growing in the lowlands.

Decreasing abundance of Pinus pollen in association with the increased abundance of thermophilous and herbaceous taxa over such wide areas (at least $400 \mathrm{~km}$ extent covering most areas of the southern side of the Alps) probably reflects the vegetational or environmental effects of climatic change at ca 13,100-12,800 cal yr BP. For this period non-pollen evidence of climatic change is still very rare south of the Alps, but several paleoclimatic records from the Northern Alpine forelands point to strong climatic oscillations during this period, which are also recorded in the Greenland ice cores (von Grafenstein et al., 2000; Ammann et al., 2000; Brooks, 2000; Schwander et al., 2000; Heiri and Millet, 2005). For this period the paleoclimatic series from the Alps and Greenland document a pronounced general climatic cooling event reaching about -1.5 to $-2{ }^{\circ} \mathrm{C}$ in and around the Alps at ca $13,100-12,900$ cal yr BP. This so-called Gerzensee oscillation (Eicher, 1987), comprises the Greenland Interstadial event GI-1b at around 13,000 calyr BP in the GRIP ice core (see Björck et al., 1998; Schwander et al., 2000; Johnsen et al., 2001; Heiri and Millet, 2005). Although it is likely that climatic cooling during the Gerzensee oscillation caused the increase of steppic plants such as Artemisia, it is unlikely that it contributed to the expansion of thermophilous taxa such as Quercus, Tilia, and Ulmus south of the Alps. Instead, we suggest a coeval expansion of xerophytes and thermophilous trees similar to those communities found today under dry temperate continental conditions in southeast Europe and Central Asia (e.g. Ukraine, Walter, 1974). The recent chironomid-based temperature estimates from Lac Lautrey (Heiri and Millet, 2005) show that before the onset of the YD a prominent warm temperature excursion (the warmest of the Lateglacial) occurred at ca 13,000-12,800 to $12,700-12,600 \mathrm{cal}$ yr BP. This warm phase is also recorded in the Ammersee record (von Grafenstein et al., 1999), but is less pronounced in the GRIP ice cores, where it is designated as Greenland Interstadial event GI-1a (Björck et al., 1998; Johnsen et al., 2001). We assume that climatic warming at $13,000-12,600 \mathrm{cal}$ yr BP allowed the population expansions of thermophilous taxa such as Quercus, Tilia, and Ulmus south of the Alps. However, the establishment of the thermophilous taxa in the lowlands of the Southern Alps and their forelands came to a sudden end when the YD began at ca 12,600-12,500 cal yr BP (e.g. Wick, 1996; Tinner et al., 1999; Pini, 2002; Finsinger et al., 2006). Possibly, the contrast between the broad temporal range of the expansion of taxa of the mixed oak forest $(13,100-12,800$ cal yr BP) and the sharpness of the beginning of the YD at $12,600 \mathrm{cal} \mathrm{yr} \mathrm{BP}$ reflects the dynamics of dissimilar processes. Building up populations of forest trees requires several centuries, whereas vegetational damage caused by a strong continental or hemispheric cooling such as the YD may occur within decades or less (see Bugmann and Pfister, 2000) and, therefore, be synchronous over a large area.

\subsection{The YD event at ca 12,600-11,500 calyr BP}

Recently, several studies have discussed the linkages between the Greenland ice core records and records from 
the Alps and neighbouring areas (e.g. Ammann et al., 2000; Schwander et al., 2000; von Grafenstein et al., 2000) for the Younger Drays, a climatic cooling of hemispheric and possibly global extent that reached $\mathrm{ca}-4{ }^{\circ} \mathrm{C}$ in and around the Northern Alps (von Grafenstein et al., 1999, 2000; Heiri and Millet, 2001). These very detailed and highresolution multy-proxy studies (including new oxygenisotope series) suggest that changes in Greenland and the Alps occurred synchronously. Within the uncertainties of the dating methods this conclusion is sustained by many if not all precisely dated palaeo records from the region (i.e. beginning of the YD around 12,700-12,600 cal yr BP, end of YD around 11,600-11,500 cal BP). The environmental effects of the YD (or Greenland Stadial GS-1 in the GRIP ice cores, Fig. 7), have been discussed in detail in many previous studies from the southern side of the Alps (e.g. Lang, 1961; Schneider and Tobolski, 1985; Wick, 1996; Tinner et al., 1999; Pini, 2002; Finsinger et al., 2006) and can be illustrated by consulting our key sites. The forest cover diminished conspicuously across all vegetational belts, and herbaceous taxa re-expanded together with psychrophilous trees such as P. cembra and Larix (see Fig. 6) and heliophilous Betula even in the lowlands. However, the Palughetto and Pian di Gembro records show that treeline was still above $1400 \mathrm{~m}$ during the YD. This topic is extensively discussed by Gobet et al. (2005). These authors reach the conclusion that during the YD treeline was located at about $1500-1800 \mathrm{~m}$ a.s.l. in the central, southern, and eastern Alps.

The YD (GS-1) lasted for about 1000 years and came to an abrupt end at 11,600-11,500 cal yr BP (Fig. 7), when (air) temperatures in and around the Northern Alps increased by about $4{ }^{\circ} \mathrm{C}$ within a few decades (Ammann et al., 2000; Schwander et al., 2000; von Grafenstein et al., 2000). Environments south of the Alps responded markedly to climatic warming. The lowland site Lago di Origlio suggests that vegetation changed abruptly at $11,500 \mathrm{cal} \mathrm{yr}$ BP. Psychrophilous and heliophilous trees such as Larix, P. cembra, and Betula as well as herbaceaous taxa such as Artemisia and Chenopodiaceae declined, whereas thermophilous trees such as Quercus, Ulmus, and Tilia reexpanded very rapidly (Fig. 6). In the pollen record of Lago di Avigliana the expansion of thermophilous trees in association with the decline of the psychrophilous and heliophilous taxa also occurred immediately at the beginning of the Holocene (significant zone boundary at ca 11,600 cal yr BP, see Finsinger et al., 2006). Similar vegetational responses at the beginning of the Holocene were observed at Lago di Annone (Fig. 6), though there significant vegetational changes are dated at $11,000 \mathrm{cal} \mathrm{yr}$ BP (Wick, 1996). We assume that the delay at this site is most probably an artefact generated by a sediment hiatus (Wick Olatumbosi, 1996) and/or by the absence of a radiocarbon date at $11,500 \mathrm{cal}$ yr BP (Fig. 6). In fact, this change is dated at $11,500 \mathrm{cal} \mathrm{yr} \mathrm{BP}$ at all other lowland sites in the Southern Alps (e.g. also Lago di Muzzano, Gobet et al., 2000).
Similar patterns of vegetational change also occurred at higher altitudes. The pollen record of the central Palughetto (1040 m a.s.l.) core suggests an expansion of thermophilous trees (e.g. Quercus and Ulmus) and a decline of psychrophilous, heliophilous, and herbaceous taxa (e.g. Larix, Artemisia) at ca 11,300-11,200 cal yr BP, ca 300 years after the end of the YD (PL-3/PL-4), whereas this change occurred somewhat earlier at Pian di Gembro (1350 m a.s.l.; Quercus expansion at ca 11,700 cal yr BP, but significant zone boundary PG-4/PG-5 at 11,700 cal yr BP). Our comparison across different altitudes clearly shows that the importance of thermophilous taxa (e.g. Quercus) decreased with altitude (Fig. 6). Thermophilous broadleaved taxa reached about the uppermost limit of the today's mountain belt (Gehrig, 1997), i.e. an altitude of about $1500-1600 \mathrm{~m}$ in the Southern Alps during the early Holocene. However, forest adjustment dynamics to climatic change were very rapid at the beginning of the Holocene. For instance, treeline moved $800 \mathrm{~m}$ upwards in only 200 years in the adjacent inner section of the central Alps (Tinner and Kaltenrieder, 2005).

\section{Conclusions}

Our data suggest that synchronous vegetational changes over wide areas of Northern Italy and southern Switzerland were probably a consequence of climatic changes. Macrofossils and megafossils reveal unambiguously that trees and shrubs (e.g. P. sylvestris, Picea, Larix, Betula) survived the LGM in the eastern Po-Plain or in the Alpine foreland (e.g. Paganelli, 1996; Kromer et al., 1998; Ravazzi, 2002; Kaltenrieder et al., 2004). Deglaciation pulses at 18,500-17,500 cal yr BP and the initial expansion of trees and shrubs at $18,000-17,500$ calyr BP in the formerly glaciated lowland areas were probably a result of the first climatic warming after the LGM. However, it is likely that in most of the pre-Alpine lowland post-glacial forests and open woodlands became established only at ca 16,000 cal yr BP, when the climate became warmer in the neighbouring North Atlantic region. This Southern Alpine forest-succession occurred millennia before the onset of similar processes north of the Alps at ca $14,500 \mathrm{cal} \mathrm{yr}$ BP. The divergence can be explained by the generally milder climatic conditions south of the Alps (today winter and summer temperatures $3-6^{\circ} \mathrm{C}$ warmer in comparison with Central Europe and the lowlands of the Northern Alps). The change in the Northern Alps at ca $14,500 \mathrm{cal}$ BP, however, was approximately synchronous with similar afforestation processes at the sites located in the mountain belt on the southern side of the Alps (e.g. Pian di Gembro, Palughetto, ca 1000-1800 m a.s.l.). Vegetation responded rapidly (i.e. within $200-300$ years at most) to strong climatic warming events $\left(+4-6^{\circ} \mathrm{C}\right)$ in Central Europe and the Alps at ca 14,500 and 11,500 calyr BP. Vegetation changes at 13,100-128,000 cal yr BP probably reflect high climatic variability during the Lateglacial Interstadial (e.g. Gerzensee Oscillation). The Younger Dryas cooling $\left(-4{ }^{\circ} \mathrm{C}\right.$ 
in Central Europe and the Alps) had strong effects on stands of thermophilous trees that had expanded at $13,100-12,800 \mathrm{cal}$ yr BP in the forelands of the Southern Alps, just before the onset of the Younger Dryas at $12,600-12,500$ cal yr BP.

Our records are affected by chronological uncertainties. This problem may partly be solved by improved radiocarbon chronologies. For instance, additional dates would be needed for some of the (already published) key sequences (e.g. Avigliana, Origlio, Annone, Pian di Gembro) where important climatic changes occurred. In addition, other dating methods (e.g. varve counts, tephra layers) may prove to be helpful, but unfortunately, such techniques are not applicable to all stratigraphic records. Besides improving the temporal precision, temporal resolution should be augmented to better address important questions such as the large-scale response dynamics of vegetation to climatic changes. Despite these uncertainties, our paleorecords unambiguously underscore the high sensitivity of subalpine, treeline, and alpine vegetation to climatic changes, a finding that is in agreement with previous studies (e.g. Tinner and Kaltenrieder, 2005) emphasizing that global warming may trigger rapid vegetational reorganizations of Alpine vegetation within centuries at most.

\section{Acknowledgements}

We thank P. Kaltenrieder, M. Peresani, and A. Aceti for fruitful discussions, A. Rizzi, G. Tanzi, and P. Daina for help during coring, and F. Oberli for laboratory assistance. Improvements to the manuscript by A. Long, J.J. Lowe and H.E. Wright, Jr. and an anonymous reviewer are gratefully acknowledged. GRIP, North GRIP and Ammersee data were obtained from the National Snow and Ice Data Center, University of Colorado at Boulder, and the WDC-A for Palaeoclimatology, National Geophysical Data Center, Boulder, Colorado. We are grateful to the Swiss National Science Foundation, which financed this study (SNF Nr 3100A0-101218) and to the Azienda Regionale Veneto Agricoltura for a grant to initiate preliminary studies at Palughetto.

\section{References}

Ammann, B., Birks, H.J.B., Brooks, S.J., Eicher, U., Grafenstein von, U., Hofmann, W., Lemdahl, G., Schwander, J., Tobolski, K., Wick, L., 2000. Quantification of biotic responses to rapid climatic changes around the Younger Dryas - a synthesis. Palaeogeography, Palaeoclimatology, Palaeoecology 159, 313-347.

Ammann, B., Birks, H.H., Walanus, A., Wasylikowa, K., 2007. Lateglacial mutidisciplinary studies. In: Elias, S.A. (Ed.), Encyclopedia of Quaternary Science, vol. 3. Elsevier, Oxford, pp. 2475-2486.

Antonelli, R., Barbieri, G., Dal Piaz, G.V., Dal Pra, A., De Zanche, V., Grandesso, P., Mietto, P., Sedea, R., Zanferrari, A., 1990. Carta geologica del Veneto 1:250.000 e relative note illustrative. S.E.L.C.A., Firenze

Avigliano, R., Di Anastasio, G., Improta, S., Peresani, M., Ravazzi, C., 2000. A new Lateglacial to Early Holocene palaeobotanical and archaeological record in the Eastern Pre-Alps: the Palughetto basin (Cansiglio Plateau, Italy). Journal of Quaternary Science 15, 789-803.

Bennett, K.D., 1996. Determination of the number of zones in a biostratigraphical sequence. New Phytologist 132, 155-170.

Beug, H.J., 1964. Untersuchungen zur spät- und postglazialen Vegetationsgeschichte im Gardaseegebiet unter besonderer Berücksichtigung der mediterranen Arten. Flora 154, 401-444.

Beug, H.J., 2004. Leitfaden der Pollenbestimmung für Mitteleuropa und angrenzende Gebiete. München.

Birks, H.J.B., Gordon, A.D., 1985. Numerical Methods in Quaternary Pollen Analysis. Harcourt Brace Jovanovich Publishers, Academic Press, London.

Björck, S., Walker, M.J.C., Cwynar, L.C., Johnsen, S., Knudsen, K.L., Lowe, J.J., Wohlfarth, B., INTIMATE members, 1998. An event stratigraphy for the Last Termination in the North Atlantic region based on the Greenland ice-core record: a proposal by the INTIMATE group. Journal of Quaternary Science 13, 283-292.

Björkman, L., Feurdean, A., Cinthio, K., Wohlfarth, B., Possnert, G., 2002. Lateglacial and early Holocene vegetation development in the Gutaiului Mountains, northwestern Romania. Quaternary Science Reviews 21, 1039-1059.

Bozilova, E.D., Tonkov, S.B., 2000. Pollen from Lake Sedmo Rilsko reveals southeast European postglacial vegetation in the highest mountain area of the Balkans. New Phytologist 148, 315-325.

Brooks, S.J., 2000. Lateglacial fossil midge stratigraphies (Insecta: Diptera: Chironomidae) from the Swiss Alps. Palaeogeography, Palaeoclimatology, Palaeoecology 159, 261-279.

Bugmann, H., Pfister, C., 2000. Impacts of interannual climate variability on the past and future forest composition. Regional Environmental Change 1, 112-125.

Burga, C., 1980. Pollenanalytische Untersuchungen zur Vegetationsgeschichte des Schams und des San Bernardino-Passgebietes (Graubünden, Schweiz). Dissertationes Botanicae 56, 1-194.

Burga, C., Perret, R., 1998. Vegetation und Klima der Schweiz seit dem jüngeren Eiszeitalter. Ott Verlag, Thun.

Casadoro, G., Castiglioni, G.B., Corona, E., Massari, F., Moretto, M.G., Paganelli, A., Terenziani, F., Toniello, V.L., 1976. Un deposito Tardowurmiano con tronchi subfossili alle Fornaci di Revine (Treviso). Bollettino Comitato Glaciologico Italiano 24, 22-63.

Dansgaard, W., Johnsen, S., Clausen, H.B., Dahl-Jensen, D., Gundestrup, N., Hammer, C.U., Hvidberg, C.S., Steffensen, J.P., Sveinbjörnsdottir, A.E., Jouzel, J., Bond, G., 1993. Evidence for general instability of past climate from a 250-kyr ice-core record. Nature 364, 218-220.

Di Anastasio, G., 1995. I depositi superficiali ed i suoli dell'Altipiano del Cansiglio. Aspetti geomorfologici, paleopedologici e di geologia del Quaternario. Tesi di laurea inedita, Università di Milano.

Ehlers, J., Gibbard, P.L. (Eds.), 2004. Quaternary Glaciations-Extent and Chronology. Part I: Europe. Elsevier, Amsterdam.

Eicher, U., 1987. Die spätglazialen sowie die frühpostglazialen Klimaverhältnisse im Bereiche der Alpen: Sauerstoffisotopenkurven kalkhaltiger Sedimente. Geographica Helvetica 42, 99-104.

Finsinger, W., 2004. Forest Dynamics Under Changing Climates: History of Vegetation and Climate in Northwestern Italy. Philosophischnaturwissenschaftlichen Fakultät,. Universität Bern, Bern.

Finsinger, W., Tinner, W., van der Knaap, W.O., Ammann, B., 2006. The expansion of hazel (Corylus avellana L.) in the Southern Alps: a key for understanding its early Holocene history in Europe? Quaternary Science Reviews 25, 612-631.

Friedrich, M., Kromer, B., Spurk, M., Hofmann, J., Kaiser, K.F., 1999. Paleo-environmental and radiocarbon calibration as derived from Lateglacial/Early Holocene tree-ring chronologies. Quaternary International 61, 27-39.

Gehrig, R., 1997. Pollenanalytische Untersuchungen zur Vegetations- und Klimageschichte des Val Camonica (Norditalien). J. Cramer, BerlinStuttgart.

Gobet, E., Tinner, W., Hubschmid, P., Jansen, M., Wehrli, M., Ammann, B., Wick, B., 2000. Influence of human impact and bedrock differences 
on the vegetational history of the Insubrian Southern Alps. Vegetation History and Archaeobotany 9, 175-187.

Gobet, E., Tinner, W., Bigler, C., Hochuli, P.A., Ammann, B., 2005. Early-Holocene afforestation processes in the lower subalpine belt of the Central Swiss Alps as inferred from macrofossil and pollen record. The Holocene 15, 672-686.

Grafenstein von, U., Erlenkeuser, H., Brauer, A., Jouzel, J., Johnsen, S., 1999. A Mid-European decadal isotope-climate record from 15,500 to 5000 years B.P. Science 284, 1654-1657.

Grafenstein von, U., Eicher, U., Erlenkeuser, H., Ruch, P., Schwander, J., Ammann, B., 2000. Isotope signature of the Younger Dryas and two minor oscillations at Gerzensee (Switzerland): palaeoclimatic and palaeolimnologic interpretation based on bulk and biogenic carbonates. Palaeogeography, Palaeoclimatology, Palaeocology 159, 215-229.

Grimm, E., 1992. Tilia Version 2.0.2 and Tilia Graph 1.12. Illinois State Museum, Research and Collection Centre.

Grootes, P.M., Stuiver, M., White, J.W.C., Johnsen, S., Jouzel, J., 1993. Comparison of oxygen-isotope records from the GISP and GRIP Greenland ice cores. Nature 366, 552-554.

Heiri, O., Millet, L., 2005. Reconstruction of Lateglacial summer temperature from chironomid assemblages in Lac Lautrey (Jura, France). Journal of Quaternary Science 20, 33-44.

Heiss, A.G., Kofler, W., Oeggl, K., 2005. The Ulten Valley in South Tyrol, Italy: Vegetation and Settlement History of the Area, and Macrofossil Record from the Iron Age Cult Site of St. Walburg, vol. 1-2. PalynoBulletin of the Institute of Botany, University of Innsbruck, pp. 63-73.

Hofstetter, S., Tinner, W., Valsecchi, V., Carraro, G., Conedera, M., 2006. Late-glacial and Holocene vegetation history in the Insubrian Southern Alps - new indications from a small-scale site. Vegetation History and Archaeobotany 15, 87-98.

Johnsen, S.J., Dahl-Jensen, D., Gundestrup, N., Steffensen, J.P., Clausen, H.B., Miller, H., Masson-Delmotte, V., Sveinbjornsdottir, A.E., White, J., 2001. Oxygen isotope and palaeotemperature records from six Greenland ice-core stations: Camp Century, Dye-3, GRIP, GISP2, Renland and NorthGRIP. Journal of Quaternary Science 16, 299-307.

Johnsen, S.J., Clausen, H.B., Dansgaard, W., Fuhrer, K., Gundestrup, N., Hammer, C.U., Steffensen, J.P., 1992. Irregular glacial interstadials recorded in a new Greenland ice core. Nature 359, 311-313.

Johnsen, S.J., Clausen, H.B., Dansgaard, W., Gundestrup, N., Hammer, C.U., Andersen, U., Andersen, K.K., Hvidberg, C.S., Dahl-Jensen, D., Steffensen, J.P., Shoji, H., Sveinbjornsdottir, A.E., White, J., Jouzel, J., Fisher, D., 1997. The $\delta^{18} \mathrm{O}$ record along the Greenland Ice Core Project deep ice core and the problem of possible Eemian climatic instability. Journal of Geophysical Research 102, 26397-26410.

Kaltenrieder, P., Ammann, B., Ravazzi, C., Tinner, W., 2004. Long-term forest dymanics during the past 26,000 years at Colli Euganei (near Padova, Italy). In: Ubera, J.L. (Ed.), XI International Palynological Congress (IPC). University of Cordoba, Granada, p. 529.

Kromer, B., Spurk, M., Remmele, S., Barbetti, M., Tondello, V., 1998. Segments of atmospheric ${ }^{14} \mathrm{C}$ change as derived from Lateglacial and Early Holocene floating tree-ring series. Radiocarbon 40, 351-358.

Kucera, M., Rosell-Mele, A., Schneider, R., Waelbroeck, C., Weinelt, M., 2005. Multiproxy approach for the reconstruction of the glacial ocean surface (MARGO). Quaternary Science Reviews 24, 813-819.

Lagerklint, M.I., Wright, J.D., 1999. Lateglacial warming prior to Heinrich event 1: the influence of ice rafting and large ice sheets on the timing of initial warming. Geology 27, 1099-1102.

Lambeck, K., Yokoyama, Y., Purcell, T., 2002. Into and out of the Last Glacial Maximum: sea-level change during Oxygen Isotope Stages 3 and 2. Quaternary Science Reviews 21, 343-360.

Lang, G., 1961. Die spät- und fruhpostglaziale Vegetationsentwicklung im Umkreis der Alpen. Eiszeitalter und Gegenwart 12, 9-17.

Lehmann, H., 1959. Studien über Poljen in den Venezianischen Voralpen und in Hochapennin. Erdkunde, Band XIII.

Lister, G.S., 1988. A 15,000-year isotopic record from Lake Zürich of deglaciation climatic change in Switzerland. Quaternary Research 29, 129-141.
Litt, T., Brauer, A., Goslar, T., Merkt, J., Balaga, K., Muller, H., RalskaJasiewiczova, M., Stebich, M., Negendank, J.F.W., 2001. Correlation and synchronisation of the Lateglacial sequences in northern central Europe based on annually laminated lacustrine sediments. Quaternary Science Reviews 20, 1233-1249.

Litt, T., Schmincke, H.-U., Kromer, B., 2003. Environmental response to climatic and volcanic events in central Europe during the Weichselian Lateglacial. Quaternary Science Reviews 22, 7-32.

Lotter, A.F., 1999. Late-glacial and Holocene vegetation history and dynamics as shown by pollen and plant macrofossil analysis in annually laminated sediments from Soppensee, central Switzerland. Vegetation History and Archaeobotany 8, 165-184.

Lowe, J.J., Hoek, W.Z., INTIMATE Group, 2001. Inter-regional correlation of paleoclimatic records for the Last Glacial-Interglacial Transition: a protocol for improved precision recommended by the INTIMATE project group. Quaternary Science Reviews 20, 1175-1187.

Magny, M., Aalbersberg, G., Begeot, C., Benoit-Ruffaldi, P., Bossuet, G., Disnar, J.R., Heiri, O., Laggoun-Defarge, F., Mazier, F., Millet, L., Peyron, O., Vanniere, B., Walter-Simonnet, A.V., 2006. Environmental and climatic changes in the Jura mountains (eastern France) during the Lateglacial-Holocene transition: a multi-proxy record from Lake Lautrey. Quaternary Science Reviews 25, 414-445.

Maher, L.J., 1993. Slotdeep.exe: manual correlation using the dissimilarity matrix. INQUA Working Group on Data-Handling Methods. Newsletter 9, January $1993\langle$ http://www.kv.geo.uu.se/inqua/news9〉.

Monegato, G., Ravazzi, C., Donegana, M., Pini, R., Wick, L., Calderoni, G., Evidence of a two-fold glacial advance during the Last Glacial Maximum in the Tagliamento end moraine system (SE Alps), Quaternary Research, accepted for publication.

Moore, P.D., Webb, J.A., Collinson, M.E., 1991. Pollen Analysis, second ed. Blackwell Science Ltd, Oxford.

Niessen, F., Kelts, K., 1989. The deglaciation and Holocene sedimentary evolution of southern perialpine Lake Lugano - implication for Alpine paleoclimate. Eclogae Geologicae Helvetica 82, 252-263.

North Greenland Ice Core Project Members, 2004. High resolution record of Northern Hemisphere climate extending into the Last Interglacial Period. Nature 431, 147-151.

Orombelli, G., Tanzi, G., Ravazzi, C., 2004. Glacier extent over the Italian Alps during the LGM. In: Antonioli, F., Vai, G.B. (Eds.), Climex Maps Italy - Explanatory notes. Litho-palaeoenvironmental Maps of Italy During the Last Two Climatic Extremes, 1:1.000.000 Scale. Bologna

Paganelli, A., 1996. Evolution of vegetation and climate in the Veneto-Po Plain during the Lateglacial and the early Holocene using pollenstratigraphic data. Il Quaternario-Italian Journal of Quaternary Sciences 9, 581-590.

Pini, R., 2002. A high-resolution Lateglacial-Holocene pollen diagram from Pian di Gembro (Central Alps, Northern Italy). Vegetation History and Archaeobotany 11, 251-262.

Punt, W., Blackmore, S., 1976-1995. The Northwest European Pollen Flora, vol. I-VII. Elsevier Publishing Company, Amsterdam.

Ravazzi, C., 2002. Late Quaternary history of spruce in Southern Europe. Review Palaeobotany Palynology 120, 131-177.

Ravazzi, C., Orombelli, G., Tanzi, G., CLIMEX group, 2004. An outline of the flora and vegetation of Adriatic basin (Northern Italy and eastern side of the Apennine) during the Last Glacial Maximum. In: Antonioli, F., Vai, G.B. (Eds.), Litho-paleoenvironmental Maps of Italy During the Last Two Climatic Extremes. Explanatory Notes. Thirty second International Geological Congress, Firenze. pp. 15-20.

Reille, M., 1992-1998. Pollen et Spores d'Europe et d'Afrique du Nord. Laboratoire de botanique historique et palynologie, Marseille.

Reimer, P.J., Baillie, M.G.L., Bard, E., Bayliss, A., Beck, J.W., Bertrand, C., Blackwell, P.G., Buck, C.E., Burr, G., Cutler, K.B., Damon, P.E., Edwards, R.L., Fairbanks, R.G., Friedrich, M., Guilderson, T.P., Hughen, K.A., Kromer, B., McCormac, F.G., Manning, S., Bronk Ramsey, C., Reimer, R.W., Remmele, S., Southon, J.R., Stuiver, M., Talamo, S., Taylor, F.W., van der Plicht, J., Weyhenmeyer, C.E., 2004. 
IntCa104 terrestrial radiocarbon age calibration, 0-26zcal kyr BP. Radiocarbon 46, 1029-1058.

Salvador, A. (Ed.), 1994. International Stratigraphic Code, second ed. The Geological Society of America.

Sarnthein, M., Gersonde, R., Niebler, S., Pflaumann, U., Spielhagen, R., Thiede, J., Wefer, G., Weinelt, M., 2003. Overview of Glacial Atlantic Ocean Mapping (GLAMAP 2000). Paleoceanography 18.

Sartorio, D., 1987. Reef and open episodes on a carbonate platform margin from Malm to Cenomanian: the Cansiglio example (Southern Alps). Memorie Società Geologica Italiana 40, 91-97.

Schmidt, R., Müller, J., Descher-Schneider, R., Krisai, R., Szeroczynska, K., Baric, A., 2000. Changes in lake levels and trophy at Lake Vrana, a large karstic lake on the Island of Cres (Croatia), with respect to palaeoclimate and anthropogenic impacts during the last approx. 16,000 years. Journal of Limnology 59, 113-130.

Schmidt, R., van der Bogaard, C., Merkt, J., Müller, J., 2002. A new Lateglacial chronostratigraphic tephra marker for the south-eastern Alps: The Neapolitan Yellow Tuff (NYT) in Langsee (Austria) in the context of a regional biostratigraphy and palaeoclimate. Quaternary International 88, 45-56.

Schneider, R., 1977. Pollenanalytische Untersuchungen zur Kenntnis der spät- und postglazialen Vegetationsgeschichte am Südrand der Alpen zwischen Turin und Varese (Italien). Botanische Jahrbücher für Systematik 100, 26-109.

Schneider, R., Tobolski, K., 1985. Lago di Ganna-Lateglacial and Holocene environments of a Lake in the Southern Alps. Dissertationes Botanicae 87, 229-271.

Schwander, J., Eicher, U., Ammann, B., 2000. Oxygen isotopes of lake marl at Gerzensee and Leysin (Switzerland), covering the Younger Dryas and two minor oscillations, and their correlation to the GRIP ice core. Palaeogeography, Palaeoclimatology, Palaeoecology 159, 203-214.
Stockmarr, J., 1971. Tablets with spores used in absolute pollen analysis. Pollen et Spores 13, 615-621.

Tinner, W., Kaltenrieder, P., 2005. Rapid responses of high-mountain vegetation to early Holocene environmental changes in the Swiss Alps. Journal of Ecology 93, 936-947.

Tinner, W., Hubschmid, P., Wehrli, M., Ammann, B., Conedera, M., 1999. Long-term forest fire ecology and dynamics in southern Switzerland. Journal of Ecology 87, 273-289.

Tinner, W., Conedera, M., Ammann, B., Lotter, A.F., 2005. Fire ecology north and south of the Alps since the last ice age. Holocene 15, 1214-1226.

Trautmann, W., 1953. Zur Unterscheidung fossiler Spaltöffnungen der mitteleuropaischen Coniferen. Flora 140, 523-533.

Vai, G.B., Cantelli, L. (Eds.), 2004. Litho-palaeoenvironmental Maps of Italy During the Last Two Climatic Extremes. Map 1-Last Glacial Maximum. Museo Geologico Giovanni Capellini, Bologna.

Walter, H., 1974. Die Vegetation Osteuropas, Nord- und Zentralasiens. Gustav Fischer Verlag, Stuttgart.

Wick, L., 1996. Lateglacial and Early-Holocene palaeoenvironments in Brianza, N Italy. Il Quaternario 9, 653-660.

Wick, L., 2004. Full to Lateglacial vegetation and climate change and evidence of glacial refugia in the South-Eastern Alps. In: Ubera, J.L. (Ed.), XI International Palynological Congress (IPC). University of Cordoba, Granada, p. 529.

Wick Olatumbosi, L., 1996. Spät- und postglaziale Vegetationgeschichte den Südalpen Zwischen Comersee und Splügenpass (Norditalien). Inauguraldissertation der Philosophisch-naturwissenschaftlichen Fakultät. Universität Bern, Bern.

Wright Jr., H.E., 1991. Coring tips. Journal of Paleolimnology 6, 37-49.

Zoller, H., Kleiber, H., 1971. Vegetationsgeschichtliche Untersuchungen in der montanen und subalpinen Stufe der Tessintaler. Verhandlungen der Naturforschenden Gesellschaft in Basel 81, 90-153. 